\title{
Facies Analysis, Genetic Sequences, and Paleogeography of the Lower Part of the Minturn Formation (Middle Pennsylvanian), Southeastern Eagle Basin, Colorado
}

\section{U.S. GEOLOGICAL SURVEY BULLETIN 1787-AA}

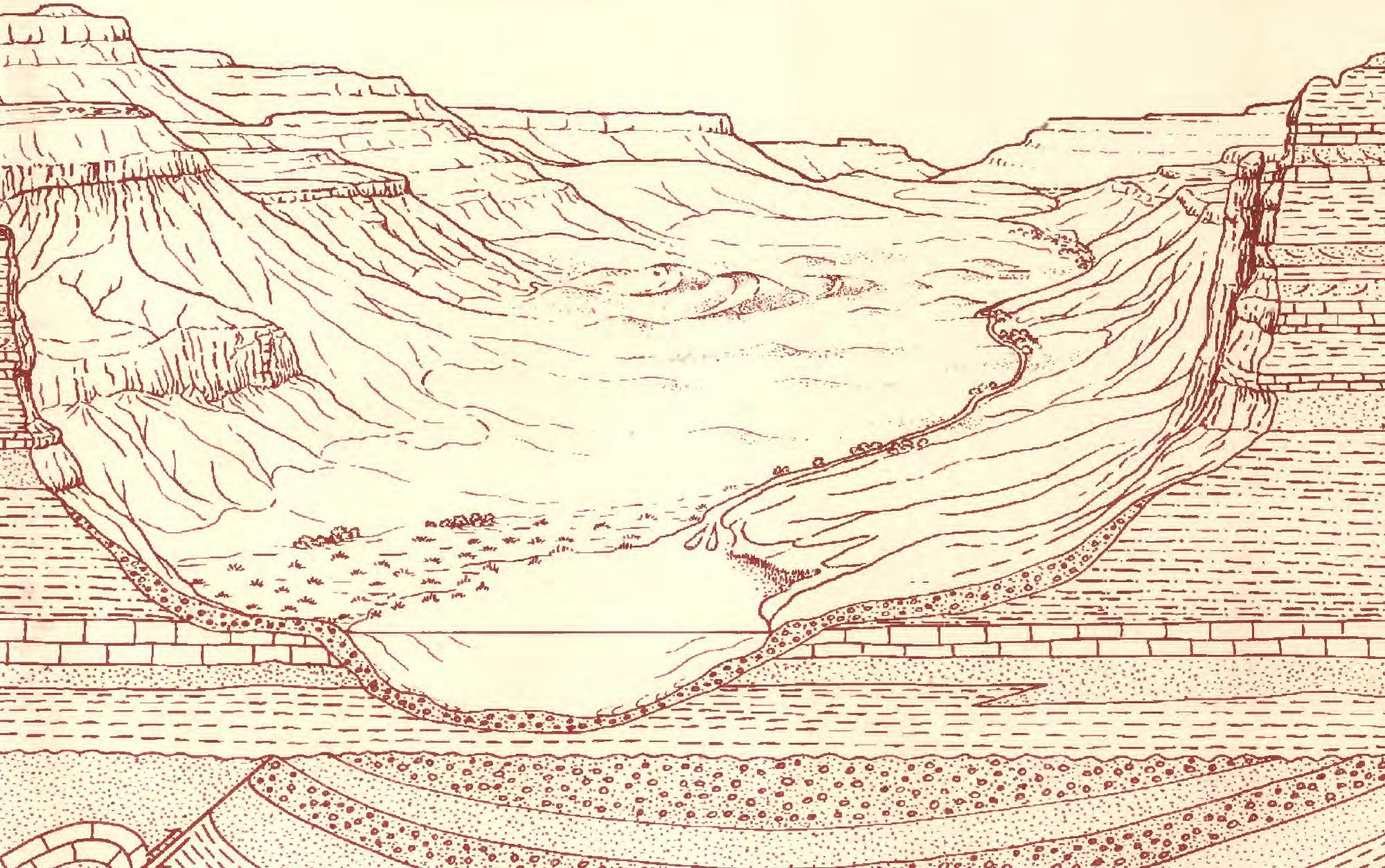



Chapter AA

\section{Facies Analysis, Genetic Sequences, and Paleogeography of the Lower Part of the Minturn Formation (Middle Pennsylvanian), Southeastern Eagle Basin, Colorado}

By JOHN A. KARACHEWSKI

A multidisciplinary approach to research studies of sedimentary rocks and their constituents and the evolution of sedimentary basins, both ancient and modern 


\title{
U.S. DEPARTMENT OF THE INTERIOR
}

MANUEL LUJAN, JR., Secretary

\author{
U.S. GEOLOGICAL SURVEY \\ Dallas L. Peck, Director
}

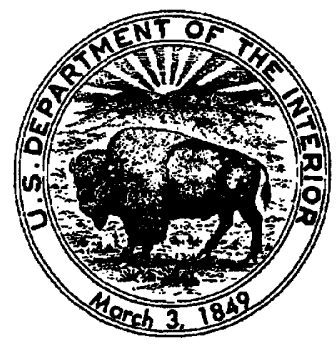

Any use of trade, product, or firm names in this publication is for descriptive purposes only and does not imply endorsement by the U.S. Government

For sale by the

Books and Open-File Report Sales

U.S. Geological Survey

Federal Center

Box 25425

Denver, CO 80225

\section{Library of Congress Cataloging-in-Publication Data}

Karachewski, John A.

Facies analysis, genetic sequences, and paleogeography of the lower part of the Minturn Formation (Middle Pennsylvanian), Southeastern Eagle Basin, Colorado /

by John A. Karachewski.

p. $\quad \mathrm{cm} . \quad-$ (U.S. Geological Survey bulletin ; 1787)

Evolution of sedimentary basins-Uinta and Piceance basins ; ch. AA)

Includes bibliographical references.

Supt. of Docs. no.: I 19.3:1787

1. Sedimentation and deposition-Colorado-Eagle County. 2. Geology, Stratigraphic-Pennsylvanian. 3. Geology,

Stratigraphic-Paleozoic. 4. Geology, Stratigraphic-Colorado-Eagle

County. 5. Paleogeography-Paleozoic. 6. Minturn Formation sedimentary

basins-Uinta and Piceance basins; ch. AA.

QE75.B9 no. 1787-AA

[QE571]

$557.3 \mathrm{~s}-\mathrm{dc} 20$

[551.7'52] 


\title{
CONTENTS
}

\author{
Abstract AA1 \\ Introduction AA1 \\ Late Paleozoic tectonic setting AA1 \\ Late Paleozoic stratigraphy of the Eagle basin AA2 \\ Geology of the Minturn-Vail area AA3 \\ Minturn Formation $\mathbf{A A 3}$ \\ Stratigraphy $\mathbf{A A 3}$ \\ Lithology and composition $\mathbf{A A 3}$ \\ Age AA3 \\ Methods of study AA3 \\ Facies analysis AA4 \\ Facies AA4 \\ Facies A-Horizontal to low-angle stratified conglomeratic \\ sandstone AA4 \\ Facies B-Structureless or crudely stratified conglomeratic \\ sandstone AA5 \\ Facies C-Structureless or normally graded sandstone AA6 \\ Facies D-Large-scale bottomset- and foreset-bedded sandstone AA6 \\ Facies E-Trough cross-stratified sandstone AA7 \\ Facies F-Tabular cross-stratified sandstone AA8 \\ Facies G-Horizontally stratified sandstone AA8 \\ Facies $\mathrm{H}$-Low-angle stratified sandstone AA9 \\ Subfacies Hhcs-Hummocky cross-stratified sandstone AA9 \\ Facies I-Ripple cross-laminated sandstone AA9 \\ Facies J-Flaser, wavy, and lenticular bedded sandstone and \\ mudstone AA10 \\ Facies K-Laminated or structureless mudstone AA10 \\ Facies L-Dolomitic biostromes and bioherms AA11 \\ Sedimentary environments AA11 \\ Alluvial-fan deposits AA11 \\ Braidplain deposits AA12 \\ Gilbert-delta deposit AA13 \\ Shoreline deposits AA16 \\ Paralic deposits AA18 \\ Offshore-marine deposits AA19
}

Genetic sequences AA20

Methods of correlation AA21

Characteristics of genetic sequences AA22

Lateral relationships between sedimentary environments within a genetic sequence AA22

Vertical stacking patterns of genetic sequences $\quad$ AA23

Controls on development of genetic sequences AA23

Paleogeography AA25

Conclusions AA28

References cited AA28 
PLATE

[Plate is in pocket]

1. Outcrop correlation of facies, sedimentary environments, and genetic sequences, Minturn Formation, southeastern Eagle basin, north-central Colorado.

\section{FIGURES}

1-2. Maps showing:

1. Geology of Minturn-Vail area AA2

2. Ancestral Rocky Mountain uplifts and basins in Colorado AA2

3. Chart showing stratigraphy of Pennsylvanian and Lower Permian rocks, Eagle basin AA3

4. Type section of Minturn Formation AA4

5. Photograph showing beds of horizontal to low-angle stratified conglomeratic sandstone (facies A) AA5

6. Photograph and schematic drawing showing large-scale, bottomset- and foreset-bedded sandstone (facies D) AA7

7-10. Photographs showing:

7. Calamites cast in growth position encased in trough cross-stratified sandstone (facies E) $\mathbf{A A 8}$

8. Climbing wave-ripple cross-laminated sandstone (facies I) with in-phase laminae AA10

9. Wavy-bedded sandstone and mudstone (facies J) AA10

10. Lionshead bioherm AA11

11. Aerial photograph showing five alluvial-fan deposits having sheet geometry AA12

12-13. Photographs showing:

12. Alluvial fan $\mathrm{V}$ (central Minturn cliffs) subdivided into sheetlike rock units by beds of finer grained sandstone AA12

13. Multistorey braidplain deposit AA13

14. Aerial photograph showing two Gilbert deltas having sheet geometry AA14

15. Photograph and schematic drawing showing Gilbert delta I subdivided into seven lobes AA15

16. Photograph showing inferred subenvironments and facies associations of Gilbert delta I AA16

17. Photograph and schematic drawing showing foreset and topset beds of Gilbert delta II exhibiting complex sigmoid-oblique geometry AA17

18-19. Lithologic sections of:

18. Regressive-shoreline deposit showing coarsening-upward sequence AA18

19. Paralic deposit lacking systematic grain-size trends AA19

20-21. Photographs and schematic drawings showing:

20. Paralic deposit exhibiting fining-upward sequence AA20

21. Relatively undeformed strata, synsedimentary thrust faults, slump folds, and detached blocks of sandstone AA21

22. Aerial photograph showing stratigraphic datum in vicinity of central and southern Minturn cliffs AA21

23. Generalized cross section showing correlation and thickness of genetic sequences AA22 
24-25. Diagrams showing:

24. Illustrations of apparent difference in number of genetic sequences between adjacent measured sections AA23

25. Two examples of variability in transgressive and regressive units within genetic sequence AA24

26. Photograph showing genetic sequence bounded by transgressive surfaces of erosion and consisting of paralic deposit, regressive surface of erosion, and alluvial-fan deposit

AA24

27-28. Diagrams showing:

27. Generalized distribution of sedimentary environments within genetic sequence 7 AA24

28. Vertical stacking patterns of genetic sequences 1 through 12

AA25

29-32. Schematic maps showing inferred paleogeography during periods of

maximum flooding and maximum progradation for genetic sequence:
29. RC4 AA25
30. 6A AA26
31. 9 and 9A AA26
32. $12 \quad$ AA27

\section{TABLES}

1. List of Minturn facies AA4

2. Percentage of deposits at each measured section

AA5 



\title{
Facies Analysis, Genetic Sequences, and Paleogeography of the Lower Part of the Minturn Formation (Middle Pennsylvanian), Southeastern Eagle Basin, Colorado
}

\author{
By John A. Karachewski ${ }^{1}$
}

\begin{abstract}
Siliciclastic and minor carbonate rocks of the lower part of the Middle Pennsylvanian Minturn Formation of northcentral Colorado were deposited in alluvial-fan, braidplain, Gilbert-delta, shoreline, paralic, and offshore-marine environments. These strata can be divided into twelve genetic sequences within clastic units B (uppermost part), C, and D of Tweto and Lovering (1977). The genetic sequences are generally bounded by transgressive surfaces of erosion, although locally they can be defined by paralic flooding surfaces. They are characterized by thin transgressive units and thick regressive units. Gradational regressive units formed by progradation of shorelines or Gilbert deltas during relative sea-level stillstands. Within nongradational regressive units, the erosional stacking of marine or paralic deposits and overlying alluvial-fan or braidplain deposits records either autocyclic or allocyclic processes. Autocyclic processes are probably related to avulsion of a braidplain or progradation of an alluvial fan into a paralic or shoreline setting, whereas allocyclic processes are probably related to regional fluctuations of relative sea level. Lowering of relative sea level results in erosional truncation of marine or paralic deposits, whereas rising of relative sea level results in aggradation of alluvial-fan or braidplain deposits. The thickening-upward trend of Minturn genetic sequences and the stacking of alluvial-fan deposits in the uppermost genetic sequences is attributed to progressively increasing tectonic activity.

Paleocurrent analysis indicates that regional paleoslope was toward the west or southwest; thus the siliciclastic detritus was derived from the ancestral Front Range uplift. The north to
\end{abstract}

Manuscript approved for publication, June 18, 1991. 80201. northwest trend of Gilbert deltas may be related to structural activity on the Avon-Edwards high at the northern end of the ancestral Sawatch uplift that resulted in development of a longitudinal or basin-axis drainage pattern.

\section{INTRODUCTION}

The Middle Pennsylvanian Minturn Formation consists of as much as $1,900 \mathrm{~m}$ of siliciclastic and minor carbonate rocks that were deposited in marine and nonmarine environments along the eastern margin of the Eagle basin in north-central Colorado during the ancestral Rocky Mountain orogeny. Although the geology and stratigraphy of the Minturn Formation at the type section (fig. 1) have been described (Tweto, 1949; Boggs, 1966; Tillman, 1971; Walker, 1972; Tweto and Lovering, 1977), the facies, sedimentary environments, genetic sequences, and paleogeography of these rocks are poorly understood. This study of the lower part of the Minturn Formation was designed to (1) conduct a facies analysis in order to interpret sedimentary environments, (2) determine the characteristics, lateral relationships, vertical stacking patterns, and controls on development of genetic sequences, and (3) reconstruct the paleogeography of the southeastern part of the Eagle basin.

\section{Late Paleozoic Tectonic Setting}

The late Paleozoic ancestral Rocky Mountains were intracratonic uplifts that formed in Colorado and the surrounding region (Mallory, 1972). The block uplifts were mountainous areas of considerable relief that were 


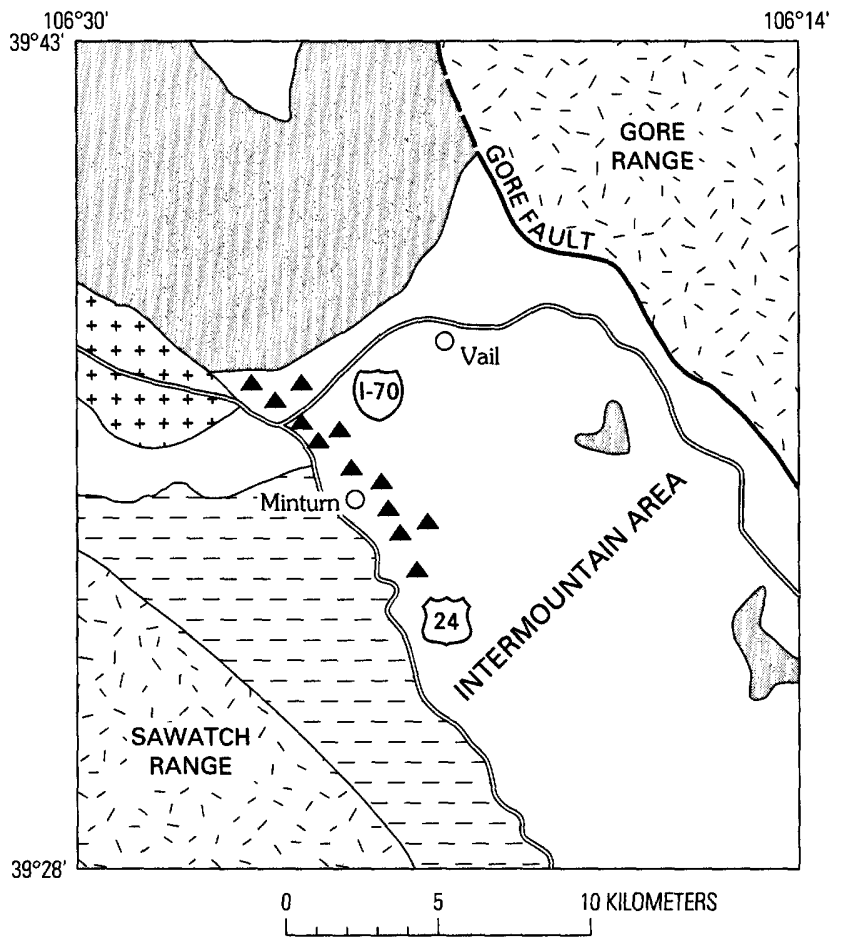

EXPLANATION

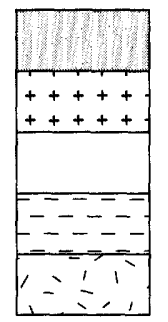

Permian and Pennsylvanian Maroon Formation

Pennsylvanian Eagle Valley Evaporite

Pennsylvanian Minturn and Belden Formations

Mississippian to Cambrian sedimentary rocks

Precambrian igneous and metamorphic rocks

- Measured section

Figure 1. Geology of the Minturn-Vail area, Colorado. Precambrian-Paleozoic contact in the Sawatch Range schematic. Location of measured sections shown in detail on plate 1. Modified from Tweto and others (1978).

apparently bounded by narrow, complex fault zones (Kluth, 1986). Major tectonic elements include the northwesttrending ancestral Front Range and Uncompahgre uplifts and the Denver basin, central Colorado trough, and Paradox basin (fig. 2). The ancestral Sawatch uplift subdivided the central Colorado trough into the Eagle basin, Aspen subbasin, and South Park subbasin (De Voto and others, 1986).

Within the Eagle basin, syndepositional faulting produced abrupt thickness variations and facies changes (De Voto and others, 1986). Based on interpretations of regional seismic lines, Waechter and Johnson (1985) recognized Pennsylvanian and Permian block faulting in the southwestem part of the Eagle basin. The precise paleogeography of the Eagle basin cannot be determined because

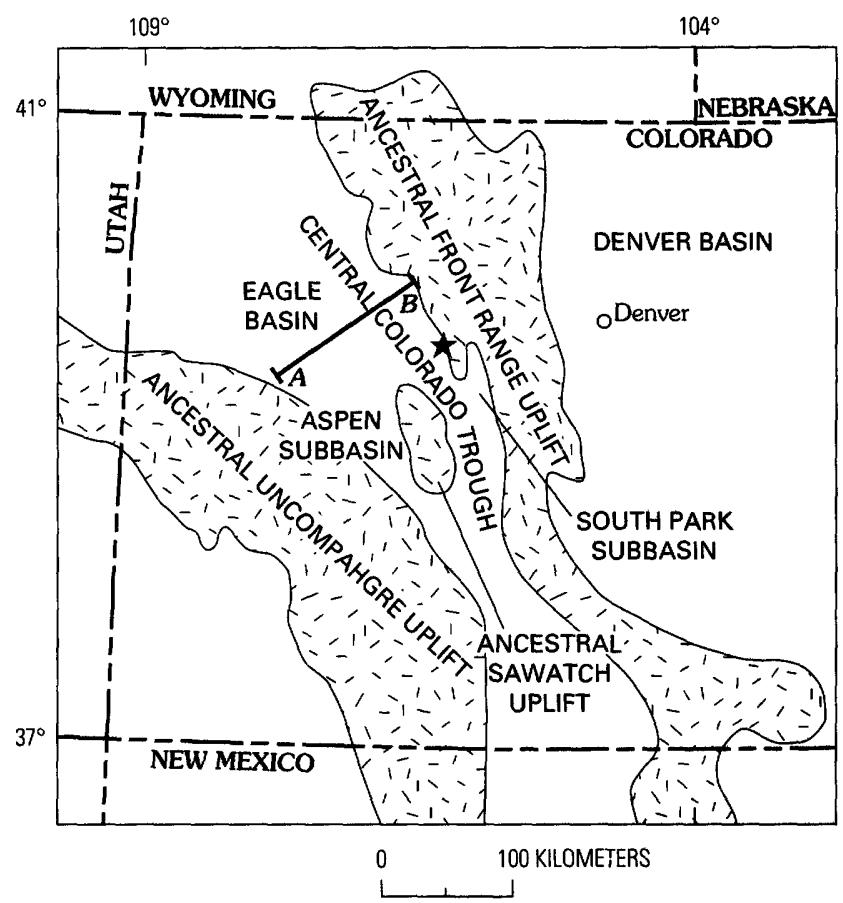

Figure 2. Ancestral Rocky Mountain uplifts and basins in Colorado. Star indicates approximate location of study area. Line $A-B$ is line of stratigraphic section shown in figure 3. Modified from Mallory (1972) and Johnson (1987).

many late Paleozoic faults were reactivated during the Laramide orogeny and in the Neogene (Tweto, 1977, 1980).

\section{Late Paleozoic Stratigraphy of the Eagle Basin}

The stratigraphy of Pennsylvanian and Lower Permian rocks in the Eagle basin is shown in figure 3. In the Minturn area, these strata include, from oldest to youngest, the Belden (as thick as $61 \mathrm{~m}$ ), Minturn (as thick as 1,921 m), and Maroon (as thick as 1,281 m) Formations (Tweto and Lovering, 1977). The Minturn Formation intertongues basinward with the Eagle Valley Evaporite (Mallory, 1971; Schenk, 1989).

The Lower and Middle Pennsylvanian Belden Formation consists of black shale, limestone, and finegrained sandstone of marine and deltaic origin (Mallory, 1972). The Middle Pennsylvanian Minturn Formation consists of conglomerate, sandstone, mudstone, dolomite, and limestone of fluvial-deltaic to marine origin (Tweto and Lovering, 1977). The Eagle Valley Evaporite consists of limestone, gypsum, halite, mudstone, and sandstone of marine to fluvial-deltaic origin (Schenk, 1987, 1989). The Upper Pennsylvanian and Lower Permian Maroon Formation consists of conglomerate, sandstone, and siltstone of fluvial and eolian origin (Johnson, 1987, 1989; Johnson and others, 1988). 


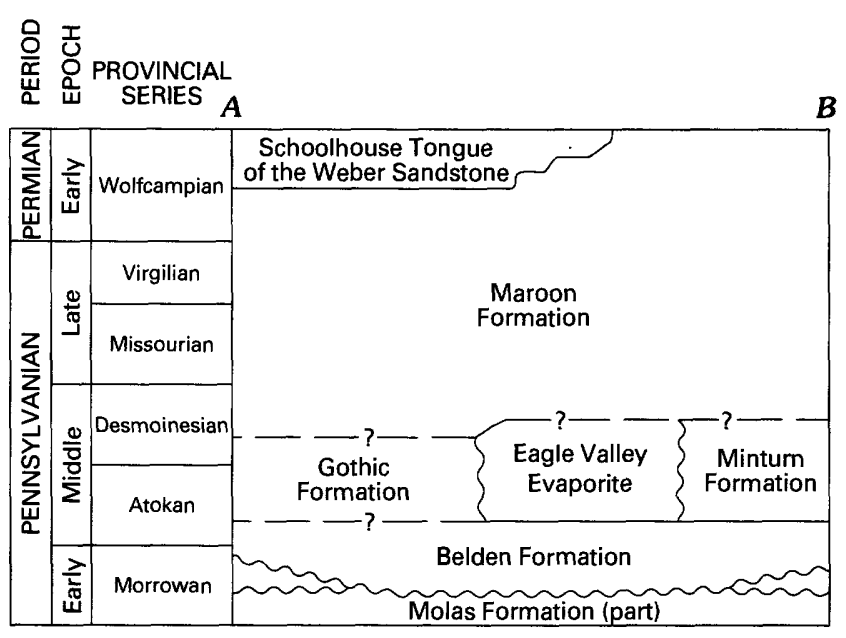

Figure 3. Stratigraphy of Pennsylvanian (320-286 Ma) and Lower Permian rocks, Eagle basin. Dashed lines and queries indicate location of boundary is uncertain. Line of section shown in figure 2. Modified from Johnson (1987).

\section{Geology of the Minturn-Vail area}

The Minturn-Vail area includes parts of three geologic and geographic areas: the Sawatch Range, an intermountain area, and the Gore Range (fig. 1). The Sawatch Range is a Precambrian-cored anticline that formed during the Laramide orogeny (Tweto, 1977). The intermountain area near Minturn and Vail is a broad syncline of Paleozoic and minor Mesozoic sedimentary rocks. The Gore fault separates the intermountain area from the Gore Range, an uplifted fault block of Precambrian rocks.

In the Minturn area, about 3,200 m of Pennsylvanian to Lower Jurassic rocks are preserved west of the Gore fault. The Upper Jurassic Morrison Formation overlaps the Gore fault and was deposited directly on Precambrian rocks of the ancestral Front Range (Tweto and Lovering, 1977). The Gore fault is a complex zone consisting of vertical to steeply dipping faults (Tweto and Lovering, 1977). The extent of back faulting along the basin margin during the late Paleozoic is uncertain because onlap relationships near the Gore fault are either poorly exposed or buried.

\section{Minturn Formation}

\section{Stratigraphy}

Because the Minturn Formation is not entirely exposed in any one location, the type section of Tweto and Lovering (1977) comprises several partial sections in the area from Gilman to the Vail ski resort, a distance of about $10 \mathrm{~km}$. The type section is subdivided into clastic units A through $\mathrm{H}$ and eight carbonate units or members (fig. 4). I examined clastic units $A$ through $D$ and the dolomite beds of Dowds and the reef dolomite of Lionshead; clastic units $A$ and $B$, however, were only examined in reconnaissance because of their poorer outcrops. Tweto and Lovering noted that the probable equivalent of the Wearyman Dolomite Member separates clastic units D and E. In contrast, based on my stratigraphic study, the Wearyman Member of Walker (1972) correlates with the lower part of clastic unit $D$, but above the reef dolomite of Lionshead.

The Minturn Formation thins rapidly toward the Gore fault, along which the lower half of the formation is missing due to onlap against the old highland (Tweto and Lovering, 1977). Onlap relationships have also been recognized near Copper Mountain (Bergendahl and Koschmann, 1971).

\section{Lithology and Composition}

The Minturn Formation consists of conglomerate, sandstone, mudstone, and minor dolomite or limestone. Conglomerates contain granules to uncommon boulders of granite, gneiss, and pegmatite. Clasts of Cambrian through Mississippian sedimentary rocks and quartz sandstone are restricted to the basal part of clastic unit A (Tweto and Lovering, 1977). The predominant rock type is a coarsegrained arkosic sandstone that contains abundant granules and scattered pebbles ("grit" of Tweto and Lovering, 1977). The petrography of Minturn sandstones was summarized by Boggs (1966). The mudstone consists of micaceous siltstone and minor claystone. Although the Minturn Formation contains both dolomite and limestone, only dolomite is present in the interval examined in this study.

\section{Age}

The Minturn Formation is Middle Pennsylvanian (Atokan and Desmoinesian) in age (Tweto and Lovering, 1977). Diagnostic macrofossils and fusulinids are most abundant in the Robinson Limestone Member (Tillman, 1971). I found molluscs and brachiopods at various stratigraphic levels but no fusulinids.

\section{Methods of Study}

My facies analysis followed the methodology outlined by Anderton (1985). Strata were described from 13 measured sections (fig. 1). Facies were defined on the basis of lithology, color, rock unit or coset thickness, bed or set thickness, texture (grain size and sorting), rock unit and bed contacts, bed geometry, physical and biogenic sedimentary structures, and fossils. Sedimentary environments were inferred on the basis of geometry, facies sequences, facies associations, and paleocurrent analysis.

Acknowledgments. - This paper is modified from a Ph.D. dissertation submitted to the Colorado School of Mines and completed under the guidance of Richard $\mathrm{H}$. 


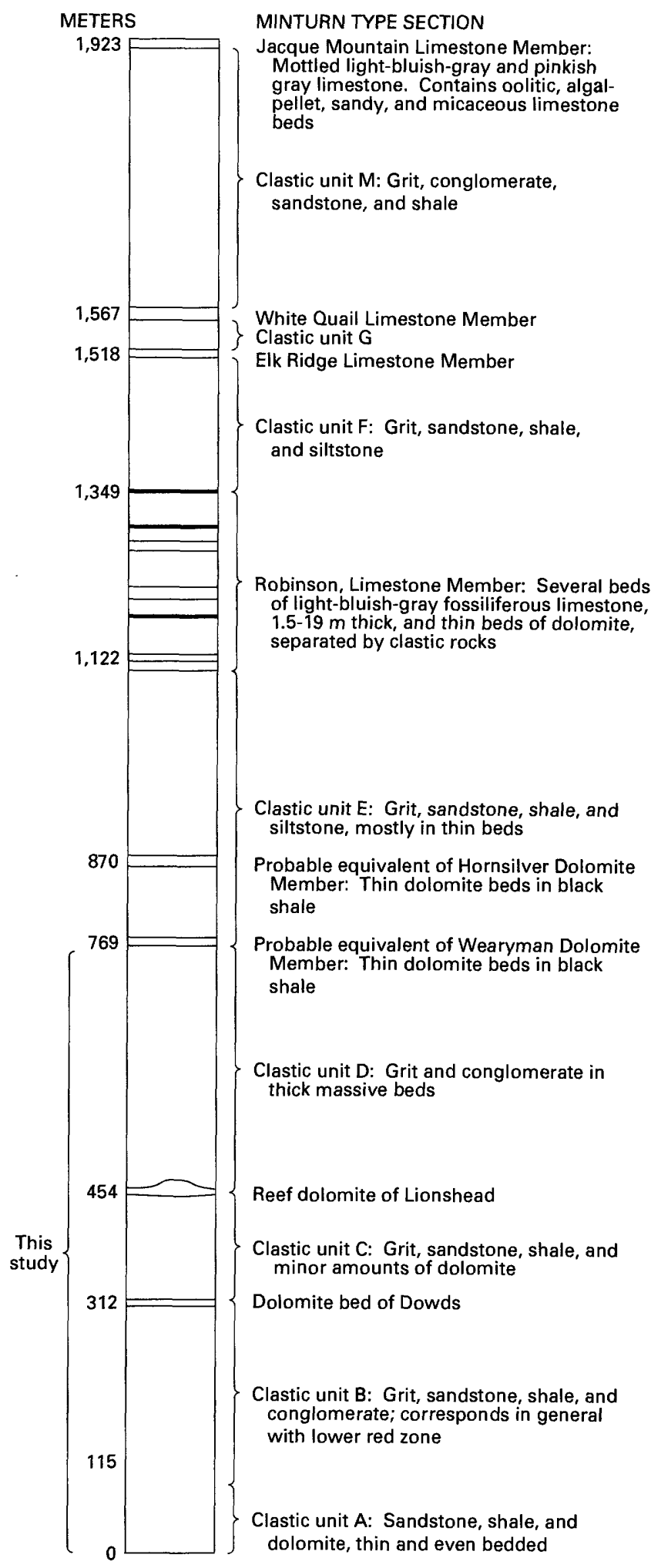

Figure 4. Type section of the Minturn Formation showing subdivisions and general character. Modified from Tweto and Lovering (1977).

DeVoto. Reviews by Samuel Y. Johnson and Christopher J. Schenk led to improvements in the manuscript and are
Table 1. List of Minturn facies

[Letters of facies should not be confused with clastic units A through H (fig. 4) of Tweto and Lovering (1977)]

\begin{tabular}{cl}
\hline Facies & Description \\
\hline A & Horizontal to low-angle stratified conglomeratic \\
sandstone. \\
B & Structureless or crudely stratified conglomeratic \\
sandstone. \\
C & Structureless or normally graded sandstone. \\
D & Large-scale bottomset- and foreset-bedded sandstone. \\
E & Trough cross-stratified sandstone. \\
F & Tabular cross-stratified sandstone. \\
G & Horizontally stratified sandstone. \\
H & Low-angle stratified sandstone. Subfacies Hhcs- \\
& Hummocky cross-stratified sandstone. \\
I & Ripple cross-laminated sandstone. \\
J & Flaser, wavy and lenticular bedded sandstone and \\
& mudstone. \\
K & Laminated or structureless mudstone. \\
L & Dolomitic biostromes and bioherms. \\
\hline
\end{tabular}

greatly appreciated. This study was supported by Chevron USA Inc., Colorado School of Mines, Colorado Scientific Society (Tweto Memorial Fund), Geological Society of America, and Ukrainian National Association. Amoco Production Company provided reprographic services.

\section{FACIES ANALYSIS}

The facies analysis is presented in two parts. The first part includes descriptions of facies (table 1) and interpretations of physical and biogenic processes. The second part provides descriptions and interpretations of sedimentary environments (table 2). Plate 1 shows the distribution of sedimentary environments for each measured section.

\section{Facies}

\section{Facies A-Horizontal to Low-Angle Stratified Conglomeratic Sandstone}

\section{Description}

Rock units comprising horizontal to low-angle stratified conglomeratic sandstone (light gray, light brown, or pink) are $50 \mathrm{~cm}-55 \mathrm{~m}$ thick, whereas beds are $3-60$ 
Table 2. Percentage of deposits of the different sedimentary environments at each measured section [Locations of sections shown on plate 1]

\begin{tabular}{|c|c|c|c|c|c|c|c|c|c|c|c|c|c|}
\hline Environment & DJ1 & DJ2 & DJ3 & NMC1 & $\mathrm{NMC}_{2}$ & GC1 & $\mathrm{GC2}$ & $\mathrm{CMC1}$ & $\mathrm{CMC2}$ & SMC1 & SMC2 & TEC1 & $\mathrm{RC} 1$ \\
\hline Alluvial fan .................... & 13 & 28 & 22 & 14 & 0 & 55 & 100 & 48 & 65 & 0 & 34 & 31 & 0 \\
\hline Braidplain .................... & 27 & 27 & 6 & 21 & 51 & 0 & $\mathbf{0}$ & $\mathbf{0}$ & $\mathbf{0}$ & 42 & 9 & 27 & $\mathbf{0}$ \\
\hline Gilbert-type delta ..... & $\mathbf{0}$ & 0 & 1 & 3 & 1 & 0 & 0 & $\mathbf{0}$ & 0 & 8 & 6 & 5 & 0 \\
\hline Shoreline ..................... & 4 & 9 & 7 & 16 & 3 & 0 & 0 & 0 & 0 & 2 & $\mathbf{0}$ & 0 & 8 \\
\hline Paralic ....................... & 10 & 19 & 6 & 27 & 42 & 0 & 0 & 25 & 5 & 24 & 15 & 18 & 92 \\
\hline Offshore marine......... & 11 & 4 & 17 & 19 & 3 & 0 & 0 & 27 & 30 & 23 & 35 & 18 & $\mathbf{0}$ \\
\hline Covered interval ....... & 35 & 12 & 40 & $\mathbf{0}$ & 0 & 45 & 0 & $\mathbf{0}$ & 0 & 0 & 0 & $\mathbf{0}$ & $\mathbf{0}$ \\
\hline
\end{tabular}

cm thick. Granules, pebbles, cobbles, and minor boulders are dispersed in a poorly to moderately sorted sandstone matrix. The largest granitic boulder is $50 \mathrm{~cm}$ in maximum dimension, and the largest intraclast is $1 \mathrm{~m}$ in maximum dimension.

Lower and upper contacts of rock units and beds are generally sharp and erosional. Beds exhibit a tabular to lenticular geometry. Low-angle beds generally dip less than $4^{\circ}$. Beds of conglomeratic sandstone exhibit repetitive, decimeter- or centimeter-scale normal grading (fig. 5). Disk- or blade-shaped clasts are imbricated with their long $a$-axis transverse to the clast-dip direction and their intermediate $b$-axis parallel with the clast-dip direction.

Horizontal to low-angle stratified conglomeratic sandstones are cut by small-scale channels that are $10 \mathrm{~cm}-1$ $\mathrm{m}$ deep and 1-4 $\mathrm{m}$ wide. These channels are filled with crudely stratified, clast-supported, polymodal conglomerates that are included in facies $\mathrm{A}$.

Locally, stratification is cut by pillar structures (type B of Lowe, 1975). The largest pillar structure (section DJ3, $302 \mathrm{~m}$ ) is $25 \mathrm{~cm}$ wide and $95 \mathrm{~cm}$ long. Pebbles and granules are concentrated near the base and margins of these structures.

\section{Interpretation}

Horizontal to low-angle stratified conglomeratic sandstones probably form by unidirectional traction transport of gravel under high-energy flow conditions. This facies is the product of intergradational sheetflood and stream- channel processes (Collinson, 1986), and vertically stacked beds are the product of a series of distinct and repetitive erosional-depositional events. Within a single bed, gradational interbedding of conglomerate and sandstone reflects fluctuating flow conditions and bedload deposition (Harms and others, 1982). The presence of pillar structures in conglomeratic sandstone suggests that deposition was rapid (Lowe, 1975; Johnson, 1986).

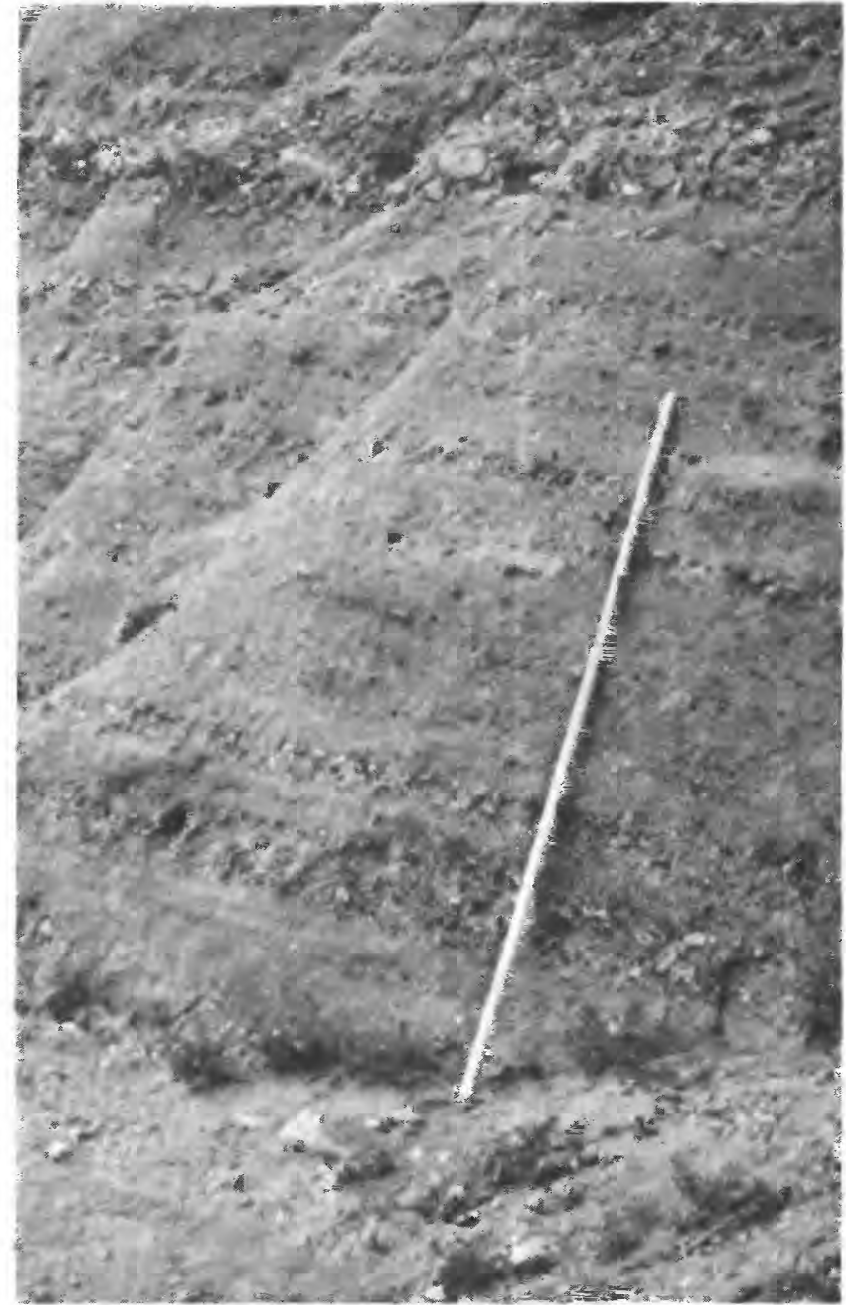

Figure 5. Beds of horizontal to low-angle stratified conglomeratic sandstone (facies A) showing decimeter-scale normal grading. Section CMC2 $(230 \mathrm{~m})$. Location of section shown on plate 1 . Jacob staff $1.5 \mathrm{~m}$ high.

\section{Facies B-Structureless or Crudely Stratified Conglomeratic Sandstone}

\section{Description}

Rock units of structureless to crudely stratified conglomeratic sandstone (light gray, grayish yellow, or light 
brown) are $10 \mathrm{~cm}-1 \mathrm{~m}$ thick, whereas beds are $10-40 \mathrm{~cm}$ thick. Granules, pebbles, and minor cobbles are generally dispersed in a poorly sorted sandstone matrix.

Lower and upper contacts of rock units and beds are sharp and generally nonerosional. Beds typically exhibit a tabular geometry, although locally they fill small-scale channels (less than $5 \mathrm{~m}$ wide and less than $1 \mathrm{~m}$ deep). Beds of structureless conglomeratic sandstone contain randomly oriented clasts. In contrast, beds of crudely stratified conglomeratic sandstone exhibit inverse to normal grading.

Facies B is always interbedded with laminated mudstone (facies $\mathrm{K}$ ) that contains a sparse molluscanbrachiopod fauna and minor burrows. Successions comprised of these two facies typically exhibit a sandstone to mudstone ratio of 5 to 1 or greater. Load and flame structures are commonly present on the soles of sandstone beds overlying mudstone (facies $\mathrm{K}$ ).

\section{Interpretation}

These structureless conglomeratic sandstones are interpreted as marine-debris flows (Middleton and Hampton, 1973) of high density and high viscosity. The disorganized clast fabric suggests that the debris flows probably traveled only short distances (Nemec and Steel, 1984). In contrast, conglomeratic sandstones having inverse to normal grading and an upward increase in sand matrix probably formed where debris flows were transformed into high-density turbidity currents (Nemec and Steel, 1984).

The interbedded laminated mudstone (facies $\mathrm{K}$ ) formed by suspension fallout from sediment plumes in the water column or by turbidity currents. The absence of wave-formed ripples and hummocky cross-stratification suggests that deposition was below storm-wave base.

\section{Facies C-Structureless or Normally Graded Sandstone}

\section{Description}

Rock units of structureless or normally graded sandstone (light gray, grayish yellow, or light brown) are 50 $\mathrm{cm}-34 \mathrm{~m}$ thick, whereas beds are $5 \mathrm{~cm}-1 \mathrm{~m}$ thick. Thicker beds of sandstone are generally amalgamated. The fine to very coarse grained sandstone is moderately sorted and contains minor granules and rare pebbles.

Lower and upper contacts of rock units and beds are sharp and erosional. Beds exhibit a tabular to broadly lenticular geometry. Flute casts and groove casts are common sole marks. Dish and pillar structures are also present.

The normally graded sandstone contains complete to incomplete Bouma sequences (Bouma, 1962). Beds having incomplete Bouma sequences generally consist of normally graded sandstone (A subdivision) and parallel-laminated sandstone (B subdivision). The structureless or normally graded sandstone (facies $\mathrm{C}$ ) is always interbedded with laminated mudstone (facies $\mathrm{K}$ ) that contains a sparse molluscan-brachiopod fauna and minor burrows. Successions comprised of these two facies typically exhibit a sandstone to mudstone ratio of 5 to 1 or greater.

\section{Interpretation}

Structureless sandstone probably formed by very rapid deposition from highly concentrated sediment dispersions or suspensions (Blatt and others, 1980). Bouma sequences record a shift from rapid suspension sedimentation to upper- to lower-flow-regime traction transport of sediment. The interbedded mudstone (facies $\mathrm{K}$ ) formed by suspension fallout from turbidity currents or sediment plumes in the water column. The absence of wave-formed ripples and hummocky cross-stratification suggests that deposition was below storm-wave base. Dish and pillar structures formed by fluidization of sediment during consolidation (Lowe, 1975).

\section{Facies D-Large-Scale Bottomset- and Foreset-Bedded Sandstone}

\section{Description}

Large-scale (3-15 m thick) bottomset- and foresetbedded sandstone is part of an assemblage (fig. 6 ) that also includes topset-bedded sandstone. Bottomset and foreset beds are composed of pebbles, granules, and medium to very coarse sand. The sandstone (light gray, grayish yellow, or yellow) is moderately to poorly sorted.

The contact between bottomset beds of sandstone and underlying or interbedded mudstone (facies $\mathrm{K}$ ) is generally gradational, although individual sandstone beds may have erosional lower contacts. Bottomset and lower parts of foreset beds have tangential bases. The contact between the upper parts of foreset and topset beds is commonly sharp and erosional (fig. 6, number 4).

Bottomset and lower parts of foreset beds are characterized by steep depositional dips (as much as $10^{\circ}$ ) and consist of interbedded structureless conglomeratic sandstone (facies B), normally graded sandstone (facies C), and laminated mudstone (facies $\mathrm{K}$ ). In addition, these beds contain in situ gastropods. In section NMC1 (97-99 m) (plate 1), bottomset beds contain ball-and-pillow structures, overturned-slump folds (amplitudes less than $25 \mathrm{~cm}$ ), and contorted stratification. Upper parts of foreset beds have a maximum dip of $22^{\circ}$ and consist of interbedded medium to very coarse grained sandstone. Locally, foreset beds are truncated by gently dipping, concave-upward surfaces (fig. 6 , unit 2). Foreset beds lack internal cross-stratification. 

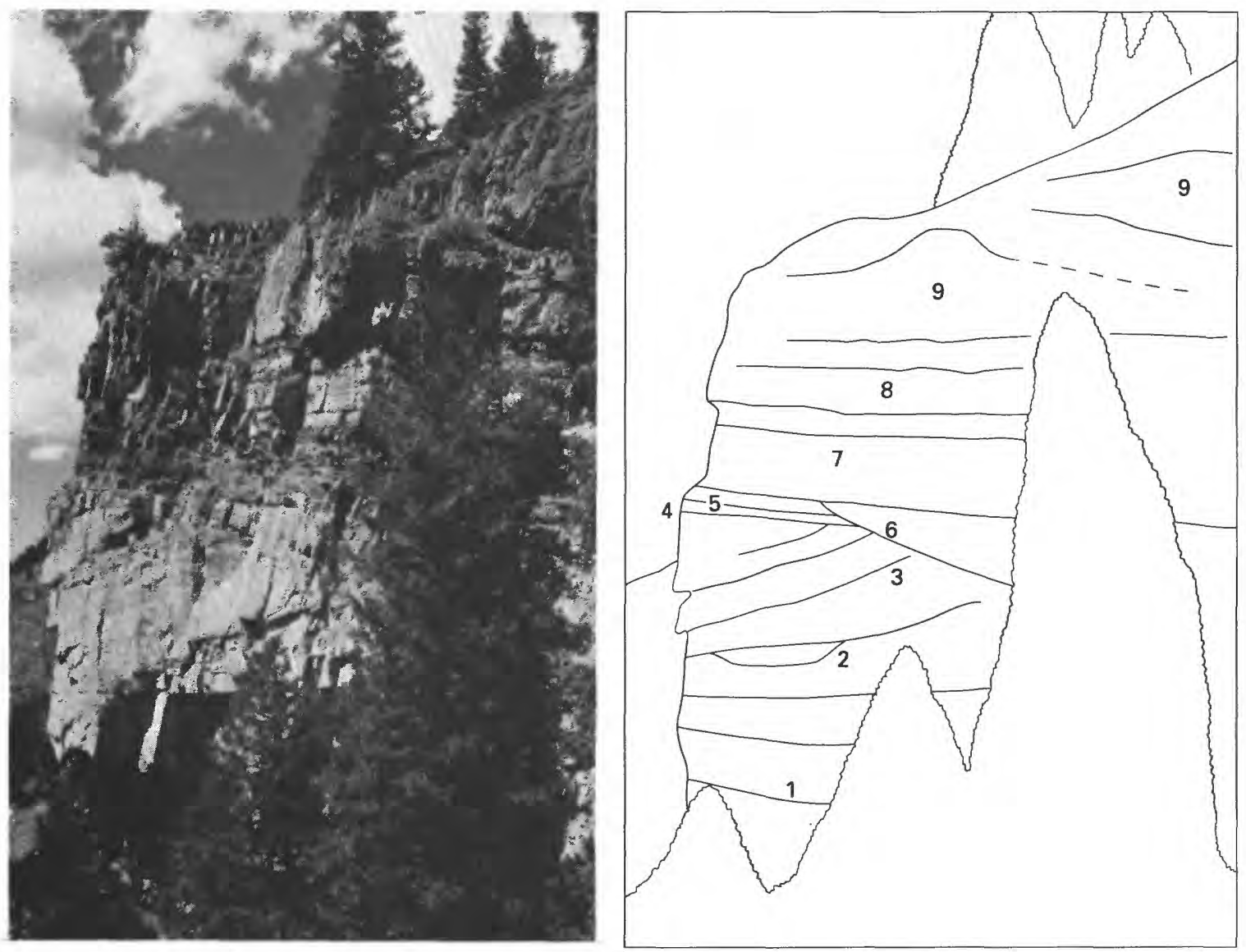

Figure 6. Large-scale, bottomset- and foreset-bedded sandstone (facies D). North of section SMC1 (135-170 m). Outcrop about $35 \mathrm{~m}$ high. Location of section shown in plate 1. Description: 1, gently dipping bottomset beds; 2 , concave-upward surface cuts foreset beds; 3 , foreset bed has apparent dip of $20^{\circ} ; 4$, erosional contact separates foreset and topset beds; 5, topset beds of horizontally stratified sandstone (facies G); 6, large-scale channel truncates topset and foreset beds; 7 , horizontally stratified sandstone (facies G) and ripple crosslaminated sandstone (facies I); 8, dolomitic biostromes (facies L) of Lionshead Member; 9, dolomitic bioherms (facies L) of Lionshead Member.

\section{Interpretation}

Bottomset-, foreset-, and topset-bedded sandstone formed by progradation of a large-scale bedform into a standing body of water. The height of the feature indicates the minimum water depth into which the bedform prograded.

Bottomset and lower parts of foreset beds record debris-flow, turbidity-current, and suspension sedimentation. Gastropods colonized the bottomset and lower parts of foreset beds during periods of low siliciclastic influx. Houck and Lockley (1986) recognized gastropods in similar beds of the Minturn Formation in the McCoy area, about $40 \mathrm{~km}$ to the northwest. The absence of backflow or counter-current ripples indicates that the lee-side vortex system (Clemmensen and Houmark-Nielsen, 1981) was poorly developed. Upper parts of foreset beds formed in response to bedload deposition and grain avalanching on a steep slope. The concave-upward surfaces cutting the foreset beds are probably slump scars.

\section{Facies E-Trough Cross-Stratified Sandstone}

\section{Description}

Cosets of trough cross-stratified sandstone (light gray, light brown, or moderate red) are $20 \mathrm{~cm}-6 \mathrm{~m}$ thick. Sets of trough cross-stratified sandstone are generally $10-40$ $\mathrm{cm}$ thick, although the maximum thickness is $1 \mathrm{~m}$. This facies consists of either poorly sorted, medium-grained to pebbly sandstone or moderately sorted, medium- to coarsegrained sandstone.

Lower and upper contacts of cosets and sets are sharp and erosional. A pebble lag commonly is present at the base of a set. In profile views, cross-strata extend for distances of as much as $5 \mathrm{~m}$. The foresets have tangential bases and exhibit either inverse grading or indistinct stratification. Foreset stratification is enhanced by heavy-mineral laminations or mudstone drapes.

Locally, trough cross-stratified sandstone encases molds and casts of Calamites in growth position (fig. 7). 
Calamites is a common late Paleozoic tree that had wide geographic distribution (Read and Mamay, 1964). Calamites was found in the following sections: DJ2 (49 m), DJ3 (295 m), CMC2 (87 m), and SMC2 (272-276 m). Calamites trunks are exposed laterally over a distance of $100 \mathrm{~m}$ or more in section SMC2 (272-276 m). Root traces are also present.

Trough cross-stratified sandstones are uncommonly cut by pocket structures (Postma, 1983). The largest pocket structure is $38 \mathrm{~cm}$ wide and $70 \mathrm{~cm}$ long. Pebbles and granules are concentrated near the base and margins of these structures.

\section{Interpretation}

Trough cross-stratified sandstone formed under lower flow regime conditions by migration of three-dimensional bedforms (dunes and megaripples) (Harms and others,

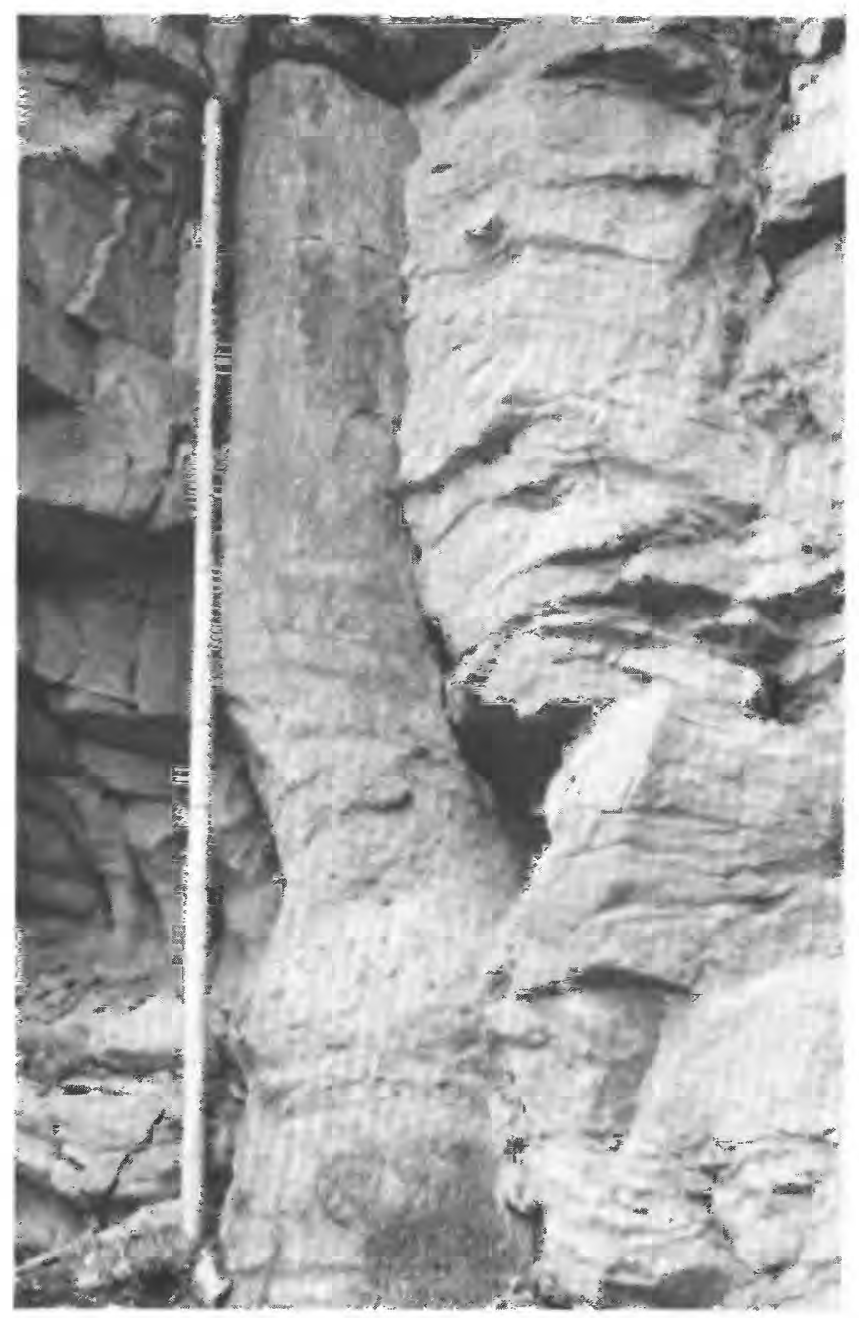

Figure 7. Calamites cast in growth position encased in trough cross-stratified sandstone (facies E). Section SMC2 (272-276 $\mathrm{m})$. Jacob staff $1.5 \mathrm{~m}$ high. Location of section shown on plate 1.
1982). Distinct foreset stratification formed when avalanche and suspension sedimentation was intermittent, whereas indistinct foreset stratification formed when avalanche sedimentation was continuous.

The preservation of Calamites in growth position suggests that sedimentation was rapid. It is uncertain whether the Calamites trunks were buried during a single or several depositional events. If several depositional events were involved, they must have occurred over, at most, several decades; otherwise the trees would have decayed or toppled. The pocket structures in conglomeratic sandstone also suggest that deposition was rapid (Postma, 1983; Johnson, 1986).

\section{Facies F-Tabular Cross-Stratified Sandstone}

\section{Description}

Tabular cross-stratified sandstone (light gray, light brown, or moderate red) is less common than trough cross-stratified sandstone. Sets are $10 \mathrm{~cm}-1.5 \mathrm{~m}$ thick. This facies consists of either poorly sorted, medium-grained to pebbly sandstone or moderately sorted, medium- to coarsegrained sandstone.

Lower and upper set contacts are sharp and either erosional or nonerosional. Erosional contacts are most common where the facies is interbedded with horizontal to low-angle stratified conglomeratic sandstone (facies A). Beds typically exhibit a tabular geometry. Several sets were traced for distances of $15 \mathrm{~m}$ or more. Foresets have planar bases and dip about $25^{\circ}-30^{\circ}$. Locally, foreset bedding is enhanced by mudstone drapes.

\section{Interpretation}

Tabular cross-strata formed under lower flow regime conditions by migration of two-dimensional bedforms (Harms and others, 1982). Sets of tabular cross-strata greater than $1 \mathrm{~m}$ in height and $10 \mathrm{~m}$ in length probably formed as sandwaves (Collinson and Thompson, 1982). Sandwaves develop at lower flow velocity for a given flow depth than do dunes.

\section{Facies G-Horizontally Stratified Sandstone}

\section{Description}

Rock units of horizontally stratified sandstone (flat beds, parallel lamination, planar lamination, or plane beds) are $10 \mathrm{~cm}-2 \mathrm{~m}$ thick, whereas laminations and thin beds are from several millimeters to $2 \mathrm{~cm}$ thick. Horizontally stratified sandstone (light gray, light brown, or red) consists of either poorly sorted, medium to very coarse grained sandstone containing granules and minor pebbles or wellsorted, fine- to medium-grained sandstone. 
Lower and upper contacts of rock units and beds are either erosional or nonerosional. Strata exhibit a tabular geometry. Parting or current lineation on bedding planes is uncommon. Locally, this facies contains desiccation cracks, root traces, burrows, and convolute laminations.

\section{Interpretation}

Horizontal stratification is produced under a wide range of current velocities. This facies may form by (1) unidirectional upper- or lower-flow-regime currents, (2) bior multi-directional oscillatory flow with high orbital velocities, (3) settling without traction transport, and (4) migration of very low amplitude bed forms (Harms and others, 1982). Convolute lamination suggests that deposition was rapid or that loading of poorly consolidated and saturated sediments occurred.

\section{Facies H-Low-Angle Stratified Sandstone}

\section{Description}

Cosets of low-angle stratified sandstone (light gray, light brown, or red) are $50 \mathrm{~cm}-2 \mathrm{~m}$ thick, whereas sets are $5-30 \mathrm{~cm}$ thick. The fine to very coarse grained sandstone generally is well sorted. This facies is distinguished from horizontal to low-angle stratified conglomeratic sandstone (facies A) by its finer grain size (granules and pebbles are rare) and thin bedding or laminations.

Lower and upper contacts of cosets and sets are sharp, erosional, and wedge shaped. Internally, stratification consists of low-angle laminations and thin beds (dips commonly less than $4^{\circ}$ ) that are parallel with set contacts or onlap them with slight divergence. Where present, granules and pebbles are segregated into discrete and laterally continuous (tens of meters) beds. Associated sedimentary structures include heavy-mineral laminations and uncommon burrows.

\section{Interpretation}

Low-angle stratified sandstone formed by very shallow and energetic, bi- or multi-directional oscillatory flow in the swash zone (Harms, 1979). The laminae were deposited by suspension clouds generated by incoming waves (Reineck and Singh, 1980). The discrete and laterally continuous beds of granules and pebbles are similar to wave-worked gravels described by Clifton (1973). Erosional set contacts were probably caused by variations in wave depth, velocity, and direction.

\section{Subfacies Hhcs-Hummocky Cross-Stratified Sandstone}

\section{Description}

Hummocky cross-stratified sandstone is a minor subfacies of the low-angle stratified sandstone. Cosets are 20 $\mathrm{cm}-2 \mathrm{~m}$ thick, whereas sets are $5-20 \mathrm{~cm}$ thick. The fine- to medium-grained sandstone (light gray or light brown) is moderately sorted.

Lower and upper contacts of cosets and sets are sharp, erosional, and gently curved. Internally, thin beds and laminations exhibit hummock and swale geometry and may thicken laterally within a set. Wavelengths of hummocks and swales are from 1 to $3 \mathrm{~m}$. Associated strata include mudstone (facies $\mathrm{K}$ ) and wave-ripple cross-laminated sandstone (facies I).

\section{Interpretation}

Harms (1979) and Walker (1979) suggested that hummocky cross-stratification forms by storm-wave processes in areas below the depth for normal fair-weather wave reworking. Deposition of hummocky cross-strata involves both lateral tractive flow due to wave oscillation and fallout from suspension (Dott and Bourgeois, 1982). Where preserved, associated wave ripples and laminated mudstone record waning of storm activity and the return to fairweather sedimentation.

\section{Facies I-Ripple Cross-Laminated Sandstone}

\section{Description}

Cosets of ripple cross-laminated sandstone (light gray, light brown, or moderate red) are $5-60 \mathrm{~cm}$ thick, whereas sets are $1-5 \mathrm{~cm}$ thick. Ripple cross-lamination is present in moderately to well sorted, fine- to mediumgrained sandstone. This facies is subdivided into currentformed ripples and wave-formed ripples.

Two types of current-ripple cross-lamination were recognized. The more common type consists of sets bounded by almost flat, sharp and erosional surfaces. The second type is uncommon and consists of sets that have preserved stoss-side laminae. In both types, the foreset laminae have tangential bases.

Wave ripples exhibit rounded, peaked, or flat-topped crests. Their internal structure consists of either formdiscordant laminae or unidirectional laminae (Tucker, 1982). Climbing wave-ripple cross-lamination is shown in figure 8. Locally, ripple crestlines are burrowed.

\section{Interpretation}

Ripple cross-laminations resulted from unidirectional currents, oscillatory waves, or combined flows. Currentformed ripples were produced under unidirectional lower flow regime conditions. The type of current-ripple crosslamination (erosional versus nonerosional stoss sides) is determined by sediment accumulation rate (Allen, 1968).

Wave-formed ripples were produced by oscillatory and combined flow(s). Form-discordant wave ripples resulted from modification of older ripple forms. Wave 


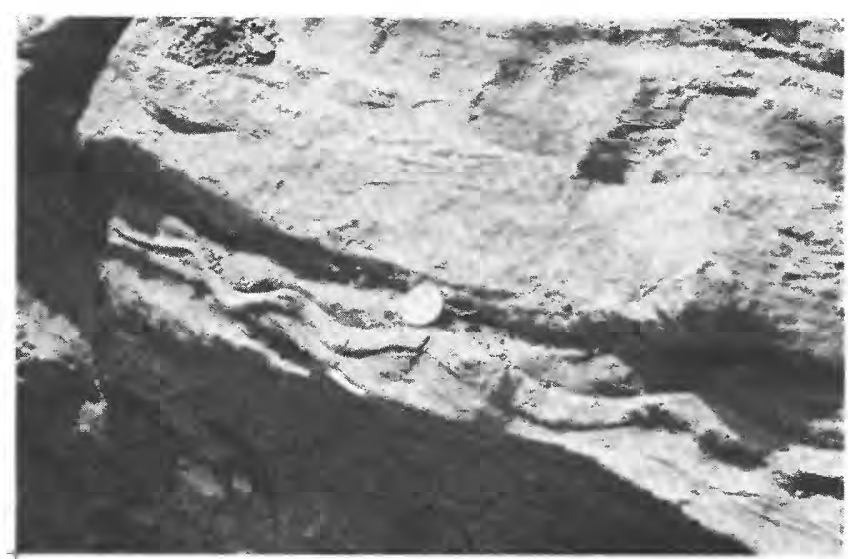

Figure 8. Climbing wave-ripple cross-laminated sandstone (facies I) with in-phase laminae (center). Section DJ3 (136 m). Outcrop about $40 \mathrm{~cm}$ high. Location of section shown on plate 1.

ripples having unidirectional foreset laminae resulted from unequal or asymmetric wave motion. The stronger component of wave motion transports sand and produces the foreset laminae, whereas the weaker component is only strong enough to maintain the symmetry of the ripple form but too weak to produce a foreset laminae. Climbing wave-ripple cross-laminations record the delicate balance between wave action and abundant sediment supply in a rapidly aggrading system (Reineck and Singh, 1980).

\section{Facies J-Flaser, Wavy, and Lenticular Bedded Sandstone and Mudstone}

\section{Description}

Flaser, wavy, and lenticular bedded sandstone is similar to ripple cross-laminated sandstone (facies I) but is distinguished by the presence of interbedded mudstone. Cosets of flaser, wavy, and lenticular bedded sandstone (light gray or light brown) and mudstone (dark gray) are 5 $\mathrm{cm}-3 \mathrm{~m}$ thick, whereas sets are $1-5 \mathrm{~cm}$ thick. Ripple crosslaminations are present in moderately to well sorted, fine- to medium-grained sandstone.

Flaser bedding consists of ripple cross-laminated sandstone containing simple or isolated mudstone drapes in ripple troughs. Wavy bedding consists of alternating ripple cross-laminated sandstone and mudstone (fig. 9). Lenticular bedding consists of mudstone having discontinuous sandstone-ripple forms. In the Minturn Formation, this facies comprises 70 percent wavy bedding, 20 percent lenticular bedding, and 10 percent flaser bedding. The facies includes small-scale (set heights less than $10 \mathrm{~cm}$ ), crossstratified sandstone that has mudstone drapes in troughs and on foresets. In addition, this facies contains desiccation cracks, burrows, and roots. Load and flame structures, sandstone dikes (as high as $60 \mathrm{~cm}$ ), and minor pocket structures are also present. Locally, this facies is interbedded with thin ( $3 \mathrm{~cm}$ or less) coal or stromatolitic biostromes (facies L).

\section{Interpretation}

Interbedded ripple cross-laminated sandstone and mudstone records fluctuations in sediment supply and level of current and wave activity (Reineck and Singh, 1980). Sandstone dikes developed when liquefied and pressurized sand is injected into fractures (Reineck and Singh, 1980). The pressure needed for injection is produced by sediment loading or accumulation of biogenic gas.

\section{Facies K-Laminated or Structureless Mudstone}

\section{Description}

Rock units of laminated to structureless mudstone (dark gray, black, or moderate red) are 1-45 m thick. Mudstones are subdivided into three types on the basis of sedimentary structures. Mudstones of type 1 consist of alternating laminations and thin beds of lighter siltstone and darker claystone. Mudstones of type 2 are interbedded with minor, sharp-based, normally graded, fine-grained sandstone beds that are as thick as $5 \mathrm{~cm}$. Mudstones of type 3 are structureless and generally bioturbated.

The mudstones may contain a molluscan-brachiopod fauna. The molluscan fauna is more common and consists of pelecypods, gastropods, and cephalopods. Composita, Orbiculate, and Productid brachiopods were recognized. Horn corals are present in sections DJ3 (27 m) and SMC2 $(137 \mathrm{~m})$. Trace fossils include Zoophycos, Curvolithus, Planolites, and Chondrites burrows. Bedding planes are commonly carbonaceous and contain comminuted plant fragments, Cordiates leaves, and rare Walchia leaves.

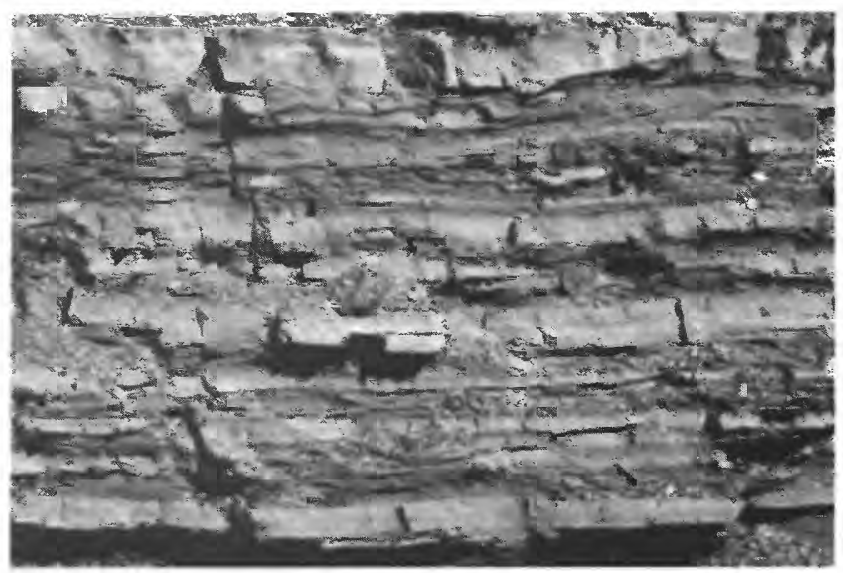

Figure 9. Wavy-bedded sandstone and mudstone (facies J). Section DJ1 $(54 \mathrm{~m})$. Outcrop about $40 \mathrm{~cm}$ high. Location of section shown on plate 1 . 
Locally, mudstones contain centimeter- to decimeterscale load and flame structures, ball-and-pillow structures, slump folds, and contorted stratification.

\section{Interpretation}

Mudstones formed in response to fluctuations in sediment supply and depositional processes. Mudstones of type 1 formed by suspension fallout from sediment plumes in the water column (Collinson and Thompson, 1982). The sharp-based, normally graded, fine-grained sandstones of type 2 were probably deposited by weak turbidity currents. Primary stratification in structureless mudstones of type 3 has been destroyed by bioturbation.

The molluscan-brachiopod fauna inhabited paralic (bay, lagoonal, or estuarine) and offshore-marine environments (Stevens, 1965, 1971; Houck and Lockley, 1986). The limited fauna suggest stressed environmental conditions that probably were caused by influx of siliciclastic detritus, turbidity in the water column, and salinity fluctuations. The absence of filter-feeding organisms such as corals and bryozoans supports this interpretation.

\section{Facies L-Dolomitic Biostromes and Bioherms}

\section{Description}

Dolomitic biostromes and bioherms are light brown on weathered surfaces and dark gray in fresh outcrops. Biostromes are $3 \mathrm{~cm}-10 \mathrm{~m}$ thick, whereas bioherms range in thickness from decimeter-scale algal heads to as much as $170 \mathrm{~m}$. Bioherms are best developed in the Lionshead and Wearyman Members (Walker, 1972).

Lower and upper rock-unit contacts are sharp and nonerosional. Both the biostromes and bioherms exhibit stromatolitic, thrombolitic (Aitken, 1967), and Chaetetes textures. The bioherms generally are present as local upgrowths on biostromes. Large bioherms are composed of stacked minibioherms (fig. 10). In general, the minibioherms have massive cores and steeply dipping (as much as $45^{\circ}$ ) flank beds. The massive-bioherm cores are made up of blue-green algae and micrite (Walker, 1972). Composita brachiopods, tubular foraminifera, and crinoids are minor constituents of bioherms (Walker, 1972). The flank beds, which contain core-derived intraclasts and bedded micrite, are intertongued with biostromes, mudstone, sandstone, and conglomerate.

\section{Interpretation}

Biostromes and bioherms consist primarily of bluegreen algae that grew in relatively shallow waters (Walker, 1972). The shift from stromatolitic to thrombolitic textures probably reflects increasing water depth (Aitken, 1967). Hartman and others (1980) proposed a sclerosponge rather

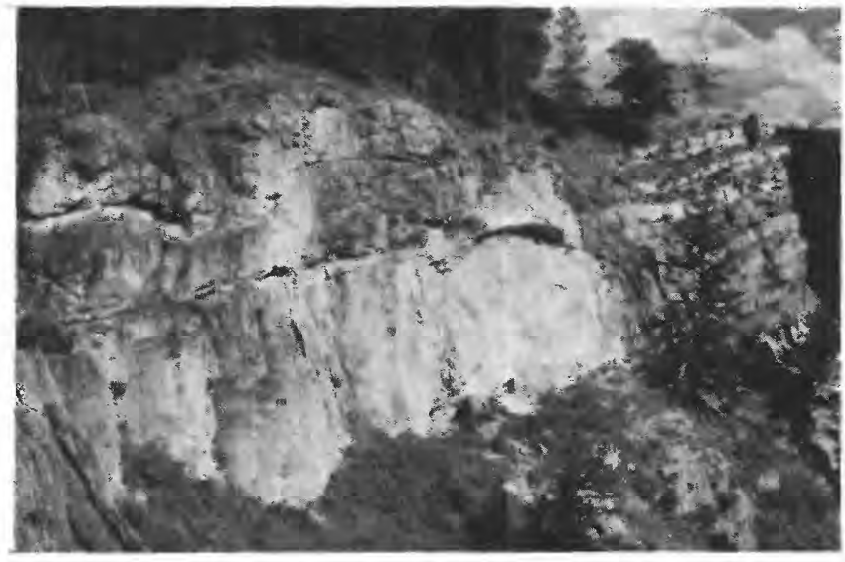

Figure 10. Lionshead bioherm, about $15 \mathrm{~m}$ high, consisting of at least three minibioherms. Beds to the right of the bioherm consist of dolomitic biostromes (facies L), laminated mudstone (facies K), and structureless or crudely stratified conglomeratic sandstone (facies B). About $900 \mathrm{~m}$ east-northeast of the Minturn radio facility.

than coralline origin for Chaetetes. Biostrome and bioherm growth was influenced by the influx of siliciclastic detritus. When siliciclastic influx was low, the algae flourished and the biostromes and bioherms expanded laterally and vertically. When siliciclastic influx was high, the algae were buried.

\section{Sedimentary Environments}

\section{Alluvial-Fan Deposits}

\section{Description}

Five alluvial-fan deposits (plate 1) were recognized; they are from 9 to $80 \mathrm{~m}$ thick. Basal and upper bounding surfaces are erosional and generally planar. These deposits exhibit either sheet (fig. 11) or cone-fan geometry. Although these deposits commonly form massiveweathering outcrops, they consist of multiple sheetlike rock units (fig. 12).

Three types of facies sequences were recognized: fining-upward sequences (alluvial fans I, II, and III), a coarsening-upward sequence (alluvial fan V), and a sequence that apparently lacks a systematic grain-size trend (alluvial fan IV).

In general, alluvial-fan deposits are composed of 75 percent horizontal to low-angle stratified conglomeratic sandstone (facies A), 15 percent horizontally stratified sandstone (facies G), 5 percent trough crossstratified sandstone (facies E), 4 percent tabular crossstratified sandstone (facies F), and 1 percent ripple cross-laminated sandstone (facies I). Calamites in growth position and rare root traces are near the top of finingupward sequences in alluvial fan I (section DJ2, $49 \mathrm{~m}$ ) and alluvial fan III (section CMC2, $87 \mathrm{~m}$ ). 


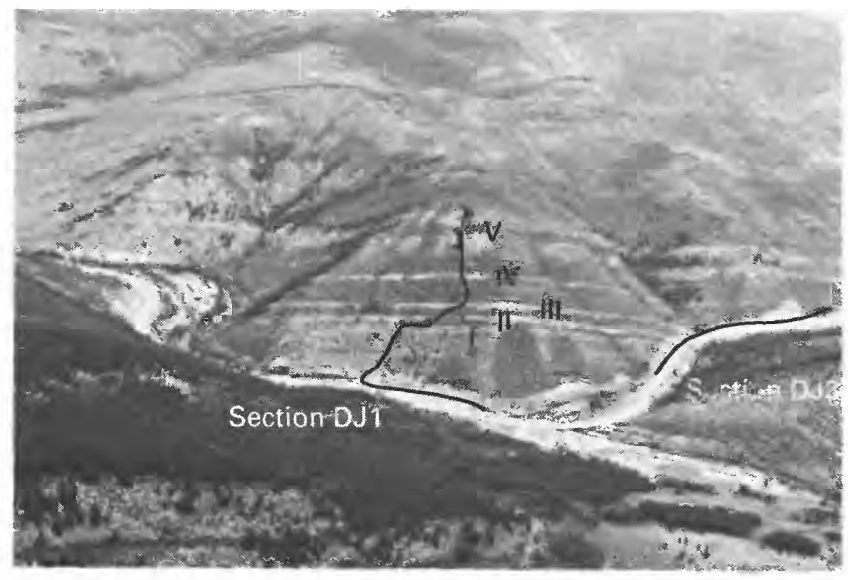

Figure 11. Aerial photograph showing five alluvial-fan deposits having sheet geometry (Roman numerals). Outcrops are oriented at a moderately oblique angle to inferred depositional strike. Lines show locations of sections DJ1 and DJ3 (lower half). View north toward Dowds Junction and Interstate 70 . Width of view about $2.5 \mathrm{~km}$.

Clast imbrication and a few trough axes were measured for paleocurrent directions. In general, each sedimentary structure exhibits a unimodal paleocurrent pattern and yields southwesterly to westerly transport directions (plate 1).

\section{Interpretation}

Alluvial-fan deposits accumulated in a mid- to distalfan setting, probably on a bajada. The absence of large-scale incised channels (fanhead trenches) and debris flows, both of which are common in proximal alluvial-fan settings (Bull, 1977; Mack and Rasmussen, 1984; Rust and Koster, 1984; Shultz, 1984), supports this interpretation. The preservation of Calamites logs in growth position and the absence of well-developed paleosols imply that these deposits accumulated under rapidly aggrading conditions.

Fining-upward sequences record progressively lower energy depositional processes (braided channel to streamflood) related to migration of fan channels or to recession of the alluvial fan. These sequences may form in response to changing local base level or climatic conditions (Heward, 1978), both of which result in gradual fan abandonment or diminution of sediment supply from the uplift. Coarseningupward sequences record progressively higher energy depositional processes (sheetflood to braided channel) and progradation of the alluvial fan (Heward, 1978). Sequences that apparently lack systematic grain-size trends record relatively uniform conditions of sedimentation.

\section{Braidplain Deposits}

\section{Description}

Nine braidplain deposits (plate 1) were recognized; they are from 2 to $66 \mathrm{~m}$ thick and exhibit a sheet- to

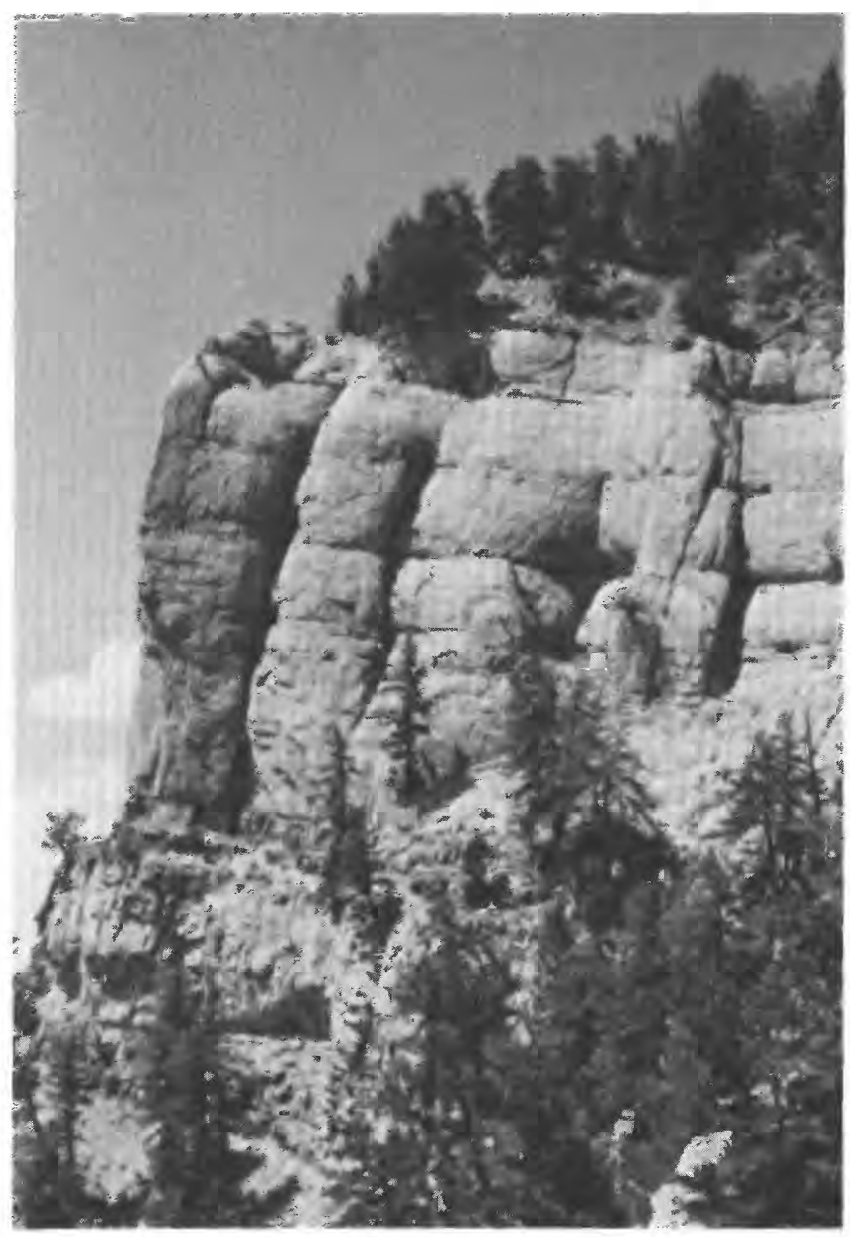

Figure 12. Alluvial fan V (central Minturn cliffs) is subdivided into sheetlike rock units by beds of finer grained sandstone that have a recessive weathering profile. This deposit is correlative with alluvial fan $V$ shown in figure 11 . Outcrop about $90 \mathrm{~m}$ high.

channel-form geometry. A braidplain deposit in the northern Minturn cliffs was traced laterally on a photograph for a distance of $1.4 \mathrm{~km}$ subparallel with inferred depositional strike before being covered. The basal bounding surface of braidplain deposits is erosional and either planar or channeled (local erosional relief generally less than $1.5 \mathrm{~m}$ ). The upper bounding surface is erosional or nonerosional and, in either case, planar. Within each sheet or channel form, scour surfaces subdivide the sandstone bodies into sheetlike or ribbon stories (fig. 13) (Friend and others, 1979).

Both braidplain deposits and stories exhibit either fining-upward sequences or sequences that apparently lack systematic grain-size trends. Stories are composed of 20-55 percent horizontal to low-angle stratified conglomeratic sandstone (facies A), 10-20 percent horizontally stratified sandstone (facies $G$ ), $20-75$ percent trough crossstratified sandstone (facies E), and 5-15 percent tabular 


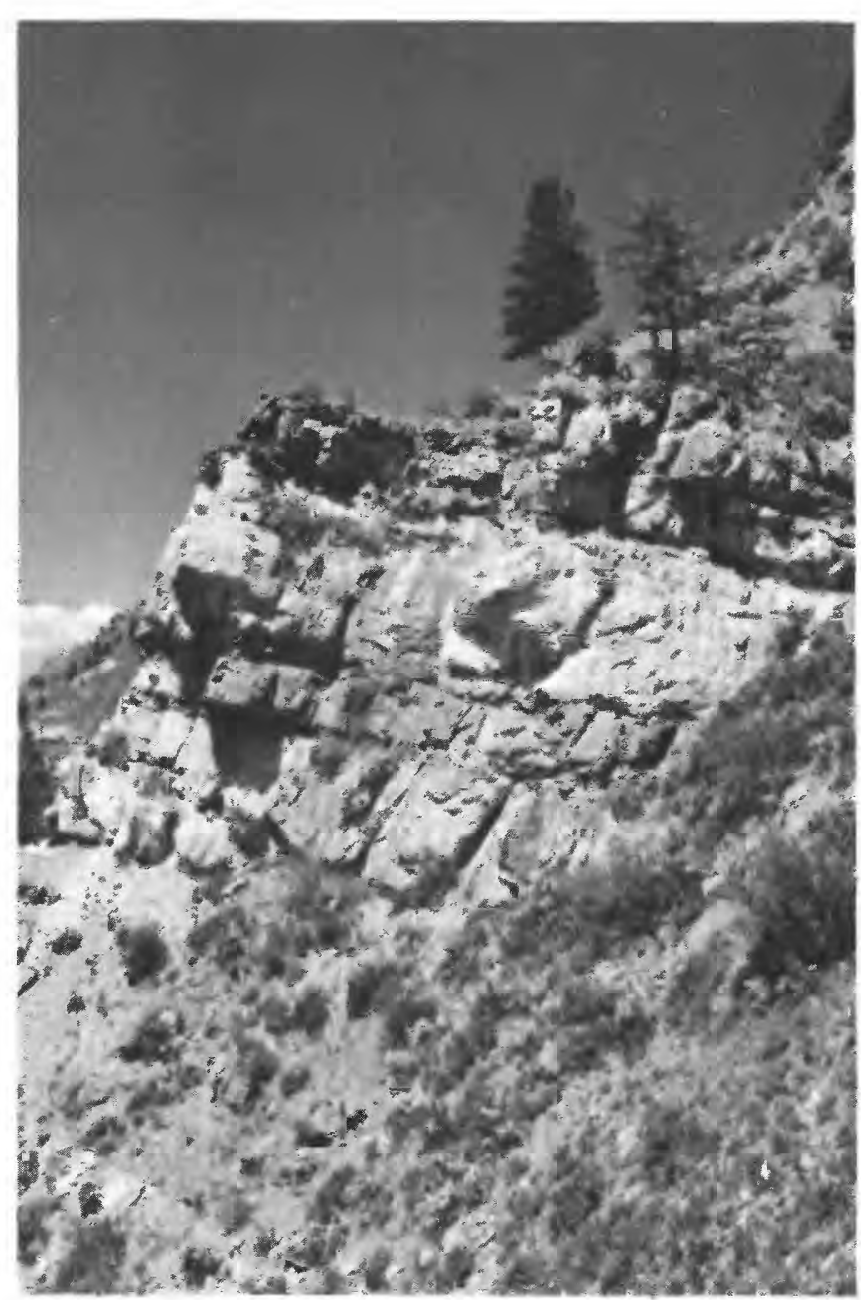

Figure 13. Multistory braidplain deposit (upper half of photograph). Outcrop about $200 \mathrm{~m}$ north of section NMC2 (90 $\mathrm{m})$ and about $40 \mathrm{~m}$ high. Location of section shown on plate 1.

cross-stratified sandstone (facies F). Locally, foreset beds of cross-strata are draped by mudstone. Although volumetrically minor, lenses of fine-grained horizontally stratified sandstone (facies G) and ripple cross-laminated sandstone (facies I) are lateral to or at the top of stories. These finer grained deposits contain rare desiccation cracks and red to green mottling, but they lack well-developed paleosols.

Although alluvial-fan and braidplain deposits are composed of the same facies, alluvial-fan deposits are thicker and coarser grained and contain beds of greater lateral continuity. In addition, trough or tabular crossstratified sandstone is less common in the alluvial-fan deposits.

Trough axes, channel axes, and a few imbricated clasts were measured for paleocurrent directions. In general, each sedimentary structure exhibits a unimodal paleocurrent pattern and yields westerly transport directions (plate 1).

\section{Interpretation}

Braidplain deposits are gradational with alluvial-fan deposits. The stacking of multiple stories within a sheet or channel form suggests deposition under aggrading conditions. Stories form due to shifting or avulsion of active stream tracts, probably during major flood events (Friend and others, 1979). Erosion and deposition within a story may record a single larger magnitude event or several smaller magnitude events. Sedimentary structures and coarse grain size indicate that these bedload-dominated streams were characterized by mobile channels of inferred low to intermediate sinuosity. Mudstone drapes within braidplain deposits suggest episodic and presumably ephemeral discharge.

\section{Gilbert-Delta Deposits}

\section{Description}

Two Gilbert-delta deposits (a shallowing-upward succession of bottomset, large-scale foreset, and topset beds), each having sheet geometry (fig. 14), were recognized. Gilbert delta $\mathrm{I}$ is $15 \mathrm{~m}$ thick and was traced laterally on an aerial photograph for a distance of $1.3 \mathrm{~km}$ before dipping into the subsurface. Gilbert delta $\Pi$ is $18 \mathrm{~m}$ thick and was traced laterally for a distance of about $200 \mathrm{~m}$ before being buried. The lower bounding surface of both deposits is gradational with underlying offshore-marine deposits. The upper bounding surface is erosional or nonerosional and in either case planar. Internally, Gilbert-delta deposits are subdivided into lobes on the basis of foreset thickness, geometry, and paleocurrents (fig. 15).

Gilbert deltas form coarsening-upward sequences (fig. 16) and are composed primarily of large-scale bottomset- and foreset-bedded sandstone (facies D). Foreset and topset beds exhibit either oblique geometry or complex sigmoid-oblique geometry (fig. 17), following the terminology of Mitchum (1977). Facies associations of topset beds are composed of either (1) low-angle stratified sandstone (facies $\mathrm{H}$ ) and horizontally stratified sandstone (facies G) or (2) horizontal to low-angle stratified conglomeratic sandstone (facies A), horizontally stratified sandstone (facies G), and trough cross-stratified sandstone (facies E).

Large-scale foreset beds and flute or groove casts from bottomset beds of sandstone were measured for paleocurrent directions. Although both deltas exhibit a unimodal paleocurrent pattern, Gilbert delta I yields northerly transport directions, whereas Gilbert delta II yields northwesterly transport directions (plate 1).

\section{Interpretation}

A marine origin for these Gilbert deltas is based on the presence of a brachiopod-molluscan fauna in the underlying mudstones. Marine Gilbert deltas (fan deltas) are 


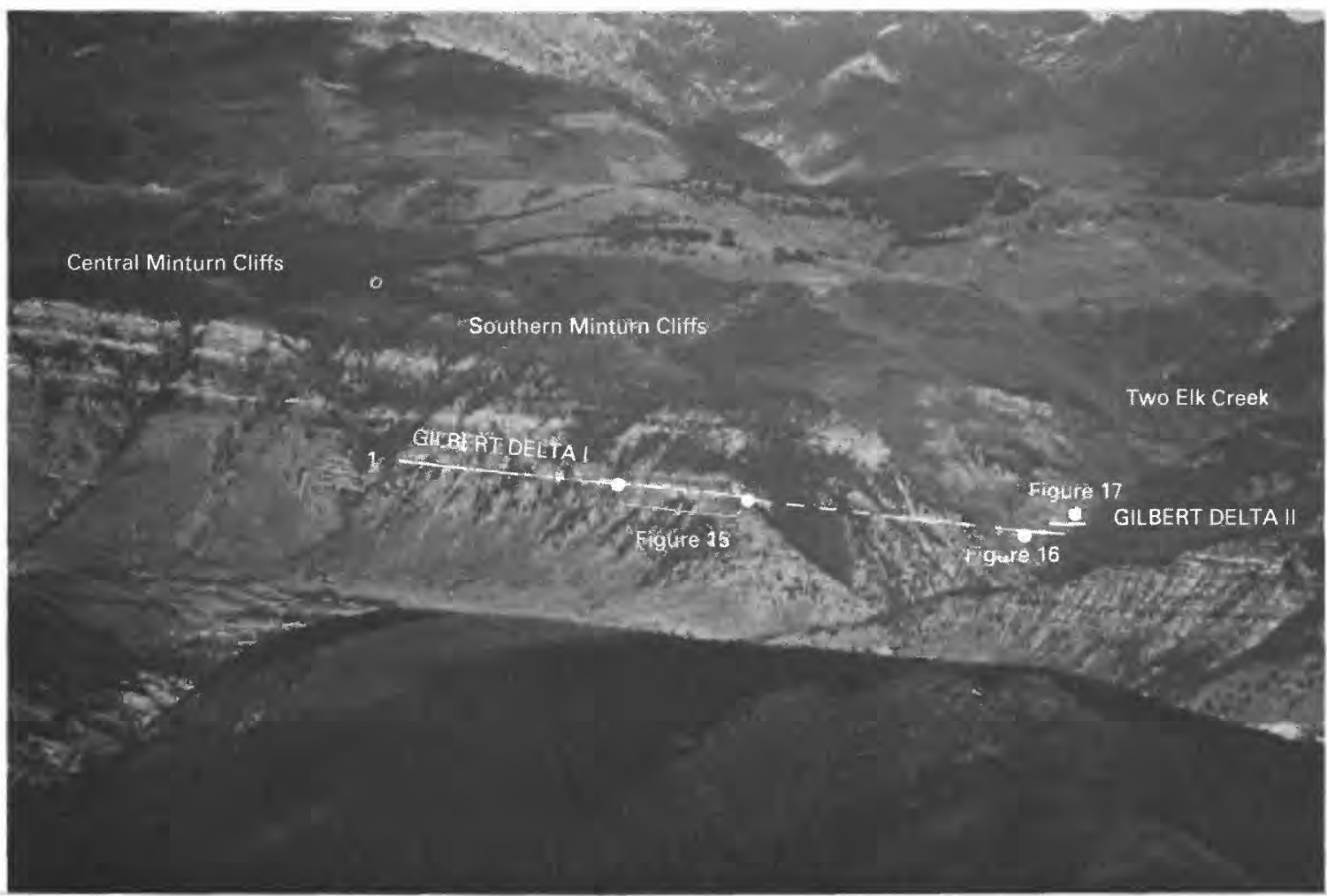

Figure 14. Aerial photograph showing two Gilbert deltas having sheet geometry. The absence of Gilbert delta I northwest of point 1 is attributed to either outcrop orientation or maximum extent of basinward progradation. Gilbert delta II crops out only in Two Elk Creek. The central and southern Minturn cliffs are oriented subparallel with inferred regional depositional strike. View looking northeast; width of view about $2.2 \mathrm{~km}$.

also present in the Minturn Formation near McCoy (Houck and Lockley, 1986). Factors favoring the development of marine Gilbert deltas include (1) rapid uplift of drainage areas, (2) a period of sea-level stillstand, (3) an abundant supply of coarse sediment to the coastlines, and (4) a basin configuration that protects deltas from strong waves and tidal currents (Colella, 1988; Massari and Colella, 1988).

The sheet geometry and coarsening-upward sequence of Gilbert deltas record progradation of distal alluvial-fan and braidplain deposits. Gilbert deltas are highly constructive systems in which fluvial processes dominate over wave and tidal processes. Deltaic lobes of variable thickness, geometry, and paleocurrents are attributed to shifts in loci of sedimentation during progradation.

Gilbert-delta deposits are subdivided into prodelta, delta-front, and delta-plain subenvironments. During highdischarge events, coarser grained bedload is transported to the steeply dipping delta front where avalanching occurs. At the same time, finer grained suspended sediment is carried away in fresh-water plumes and deposited beyond the delta front in gently inclined bottomset beds and offshore-marine mudstone beds. Delta-front slumping results in resedimentation of coarser grained detritus by turbidity currents or debris flows to lower-delta-front or prodelta subenviron- ments (Postma and Roep, 1985). Thin mudstone drapes are deposited on foreset beds during periods of low clastic influx. During these relatively quiet periods, gastropods colonize the bottomset beds.

Foreset-topset beds having oblique geometry record contemporaneous progradation, sediment bypass, and deposition below sea level (Mitchum, Vail, and Sangree, 1977). These conditions result during a relative stillstand of sea level. In contrast, foreset-topset beds having complex sigmoid-oblique geometry record contemporaneous progradation and aggradation (Mitchum, Vail, and Sangree, 1977); conditions caused by a relative rise of sea level, probably due to tectonic subsidence and (or) eustacy.

The topset beds are composed of two facies associations. The first facies association of low-angle stratified sandstone (facies $\mathrm{H}$ ) and horizontally stratified sandstone (facies G) forms under oscillatory flow conditions as a result of wave reworking of the delta front. The second facies association of horizontal to low-angle stratified conglomeratic sandstone (facies A), horizontally stratified sandstone (facies $\mathrm{G}$ ), and trough cross-stratified sandstone (facies E) is of distal alluvial-fan or braidplain origin. 

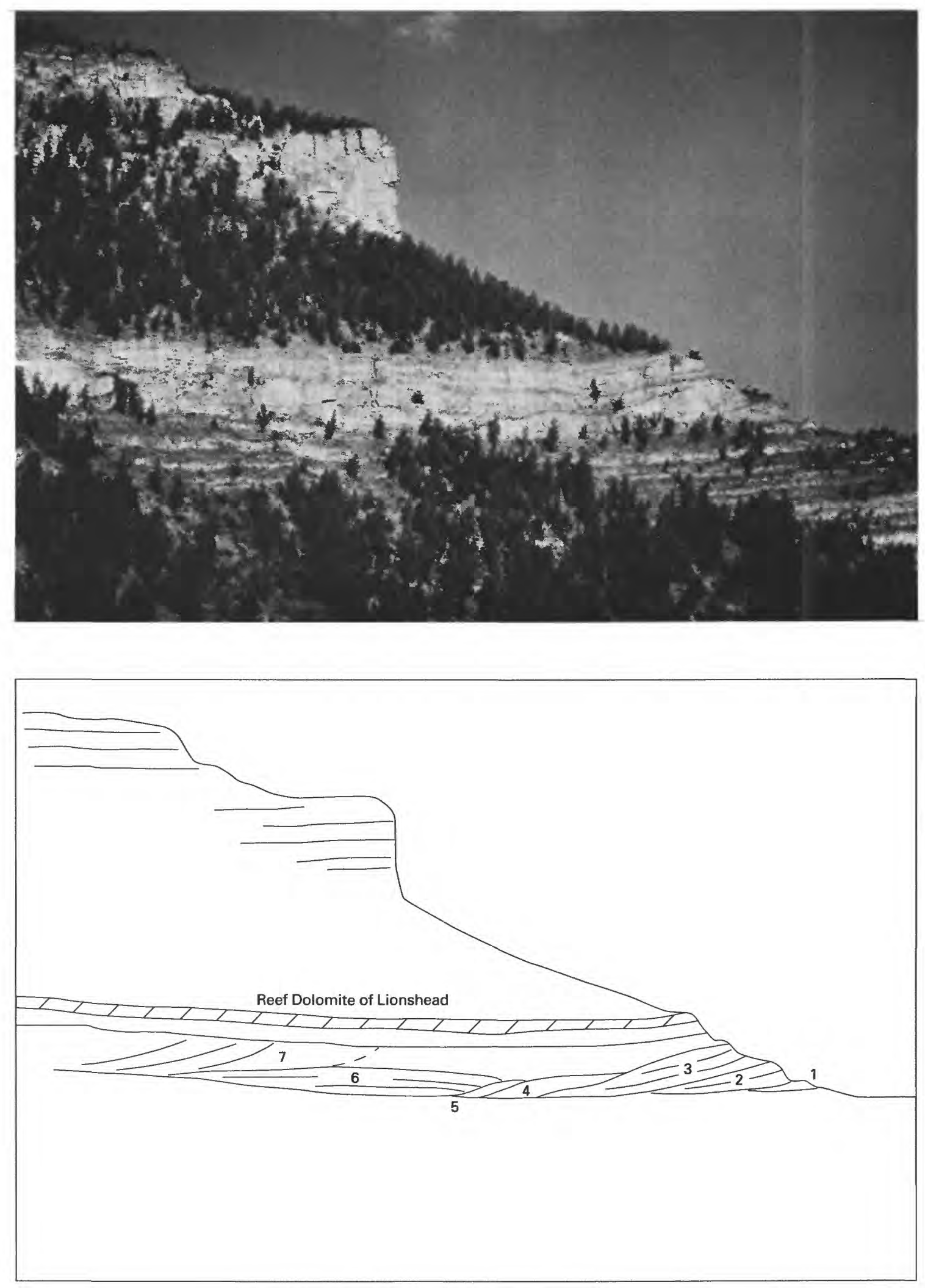

Figure 15. Gilbert delta I is subdivided into seven lobes (numbered). Outcrop is oriented subparallel with transport direction of large-scale foreset beds. Note the variable heights of large-scale foreset beds in different lobes, especially lobes 3 and 4 . In addition, lobe 6 onlaps lobe 5 and lobe 7 downlaps lobe 6. Location of outcrop shown in figure 14; width of view about $300 \mathrm{~m}$. 


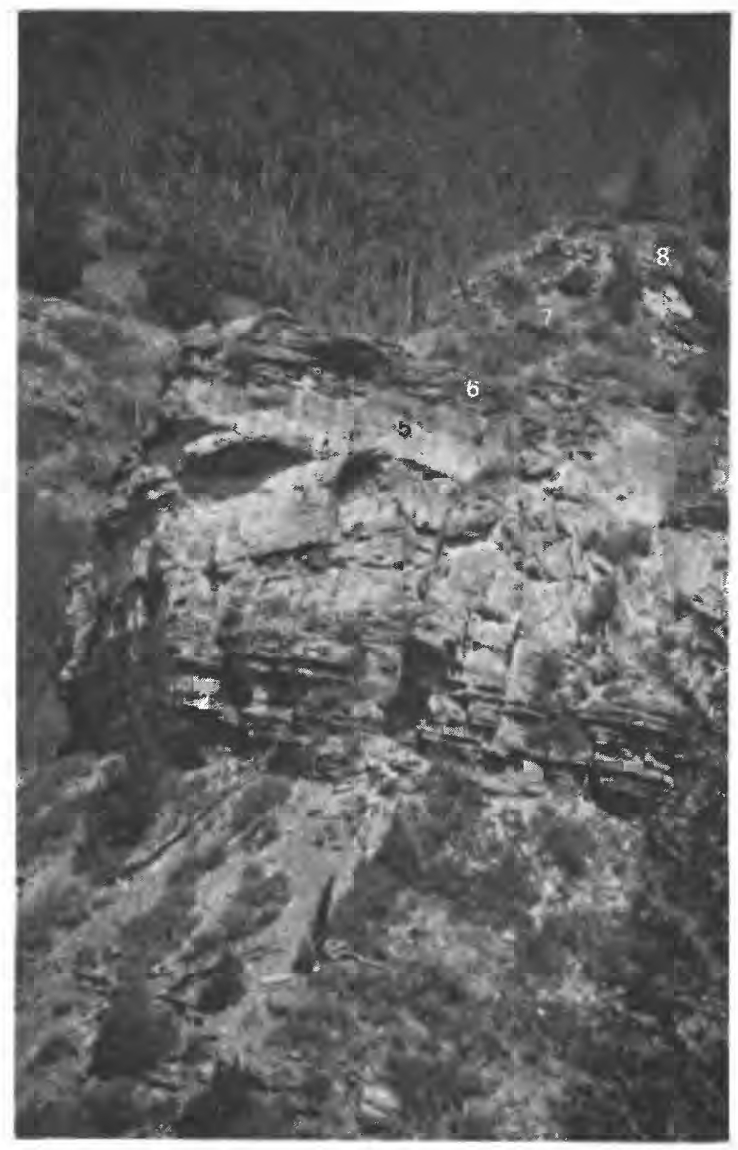

\section{DESCRIPTION}

OFFSHORE MARINE

1. Laminated mudstone (facies $\mathrm{K}$ )

PRODELTA

2. Laminated mudstone (facies $\mathrm{K}$ )

Structureless or crudely stratified conglomeratic sandstone (facies B)

Structureless or normally graded sandstone (facies C)

DELTA FRONT

3. Large-scale bottomset- and

foreset-bedded sandstone (facies D)

4. Sharp erosional contact separates foreset and topset beds

DELTA PLAIN (distal-alluvial fan or braidplain)

5. Horizontal to low-angle stratified conglomeratic sandstone (facies A)

6. Horizontally stratified sandstone (facies G)

Trough cross-stratified sandstone (facies E)

PARALIC

7. Ripple cross-laminated sandstone (facies I)

Laminated mudstone (facies $\mathrm{K}$ )

8. Dolomitic biostromes (facies $L$ ) of Lionshead Member

Figure 16. Inferred subenvironments and facies associations of Gilbert delta I. Outcrop is oriented at an oblique angle to transport direction of large-scale foreset beds. Location of outcrop shown in figure 14. View looking northwest; outcrop about $45 \mathrm{~m}$ high.

\section{Shoreline Deposits}

\section{Description}

Transgressive- and regressive-shoreline deposits were recognized (plate 1). The lower bounding surface of transgressive-shoreline deposits is erosional and has been termed a ravinement surface (Swift, 1968) or a transgressive surface of erosion (R.J. Weimer, Colorado School of Mines, oral commun., 1989). Transgressive-shoreline deposits consist of structureless, poorly sorted, medium-grained to pebbly sandstone beds that are generally less than $10 \mathrm{~cm}$ thick and laterally discontinuous. The upper bounding surface of transgressive-shoreline deposits is sharp and nonerosional. Where these thin sandstones are absent, the transgressive surface of erosion commonly separates underlying alluvial-fan or braidplain deposits from overlying offshore-marine deposits.

Four regressive-shoreline deposits (plate 1) were recognized; they are from 3 to $8 \mathrm{~m}$ thick and exhibit a sheet geometry. Regressive-shoreline deposits near Dowds Junction were traced laterally on an aerial photograph for as far as $800 \mathrm{~m}$. These deposits have a gradational lower bounding surface with underlying offshore-marine deposits. The upper bounding surface is erosional and planar. Regressive-shoreline deposits exhibit coarsening-upward sequences (fig. 18). From base to top, they are generally composed of about 5 percent hummocky cross-stratified sandstone (subfacies Hhcs), 15 percent wave-ripple crosslaminated sandstone (facies I), 60 percent horizontally stratified sandstone (facies G), 5 percent trough cross-stratified sandstone (facies E), and 15 percent lowangle stratified sandstone (facies $\mathrm{H}$ ). Locally, the upper parts of some deposits are cut by gently dipping erosion surfaces and overlain by thin pebble lags. The few trough axes measured exhibit polymodal paleocurrent directions (plate 1).

\section{Interpretation}

Transgressive surfaces of erosion and transgressiveshoreline deposits result from a relative rise of sea level. Processes associated with shoreline retreat have been discussed by Brunn (1962), Swift (1968), and Nummedal 

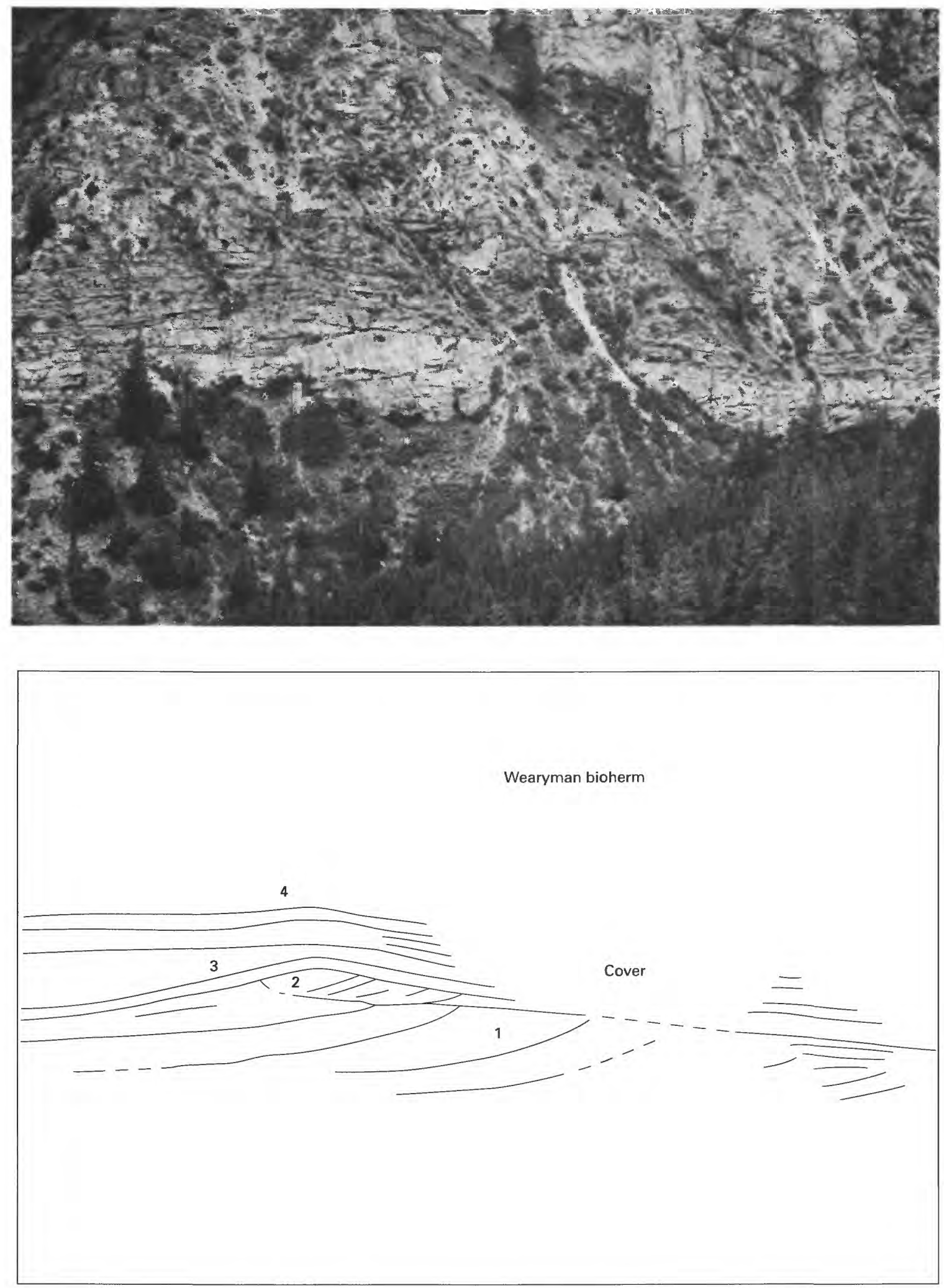

Figure 17. Foreset and topset beds of Gilbert delta II exhibiting complex sigmoid-oblique geometry. Near point 1 the apparent dip of large-scale foreset beds is $21^{\circ}$. Point 2 refers to a small bedform that prograded toward the northwest (left). Bed 3 drapes bedforms 1 and 2. Note decrease in foreset-topset dips between beds 3 and 4 . Gilbert delta II is overlain by the 170-m-thick Wearyman bioherm of Walker (1972). Structural dip is approximately $12^{\circ} \mathrm{NE}$. (right). Outcrop is oriented subparallel with transport direction of large-scale foresets. Location of outcrop shown in figure 14. View looking northwest; width of view about $40 \mathrm{~m}$ high. 


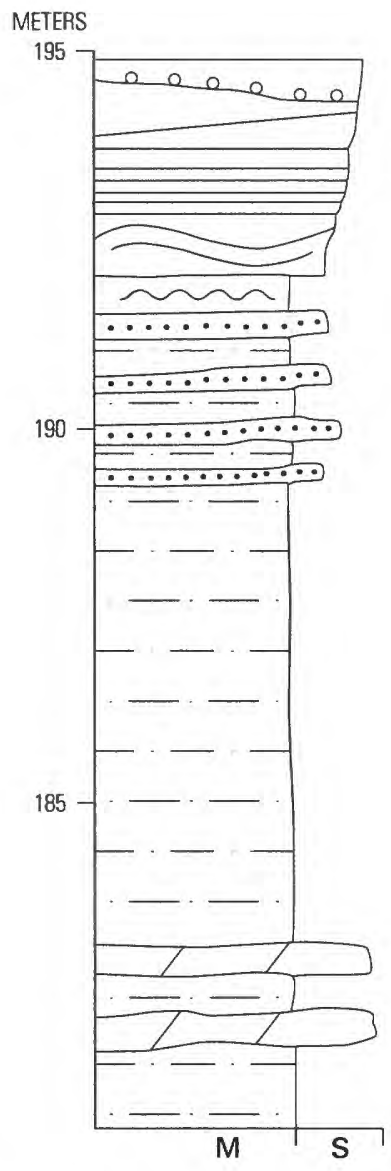

Figure 18. Regressive-shoreline deposit showing coarseningupward sequence. $M$ and $S$ refer to mudstone and sandstone, respectively. Facies symbols explained on plate 1. Location of section DJ1 (185-195 m) shown on plate 1 .

and Swift (1987). Transgressive surfaces of erosion form by surf action along a narrow zone at the foot of the shoreface. Sediment eroded from the beach by storm currents is redeposited offshore and preserved because of continuous sea-level rise. Elliot (1986) proposed that thin or attenuated ancient transgressive-shoreline deposits developed under conditions of moderately rapid sea-level rise, low subsidence rates, and minimal sediment supply.

Regressive-shoreline deposits form by progradation in a low-wave-energy setting. Limited fetch within the relatively narrow central Colorado trough was probably the main factor contributing to the low-wave-energy regime of the Minturn deposits, although coastal embayments may have also been locally important. The coarsening-upward sequence and suite of sedimentary structures reflect shoaling conditions. The interbedded laminated mudstone (facies $\mathrm{K}$ ), wave-ripple cross-laminated sandstone (facies I), and minor hummocky stratified sandstone (subfacies Hhcs) were deposited in the transition zone between the offshore and lower shoreface (Dott and Bourgeois, 1982). Fine- to medium-grained, horizontally stratified sandstone (facies G) and low-angle stratified sandstone (facies $\mathrm{H}$ ) were deposited in the lower and middle shoreface and reflect persistent and increasing wave action. Medium-grained to pebbly sandstone with horizontal stratification (facies G) and low-angle stratification (facies $\mathrm{H}$ ) was deposited in the upper shoreface and foreshore by breaker-, surf-, and swash-zone processes. Gently dipping erosion surfaces are attributed to seasonal and storm modifications of the beach profile.

\section{Paralic Deposits}

\section{Description}

Ten paralic deposits were recognized (plate 1). These deposits are characterized by highly variable facies sequences and facies associations. Descriptions of two such deposits follow.

The paralic deposit of section CMC2 (62-71 m) (fig. 19) lacks systematic grain-size trends. It was traced laterally on an aerial photograph for a distance of $400 \mathrm{~m}$ before being covered. The lower bounding surface with the underlying alluvial-fan deposit is sharp and nonerosional, whereas the upper bounding surface with the overlying alluvial-fan deposit is sharp and erosional. The deposit is composed of 70 percent flaser, wavy, and lenticular bedded sandstone and mudstone (facies J), 16 percent trough cross-stratified sandstone (facies E), and 14 percent horizontal to low-angle stratified conglomeratic sandstone (facies A). The few trough axes exhibit a bimodal paleocurrent pattern (plate 1), although southwesterly directions are more common.

The paralic deposit of sections SMC1 (152-165 m) and SMC2 $(84-96 \mathrm{~m})$ exhibits a fining-upward sequence (fig. 20). This deposit was traced laterally on an aerial photograph for a distance of $1.1 \mathrm{~km}$ before being covered. The lower bounding surface with the underlying braidplain or Gilbert-delta deposit is sharp and nonerosional, whereas the upper bounding surface with the overlying transgressive-shoreline deposit is sharp and erosional. This paralic deposit consists of 45 percent ripple cross-laminated sandstone (facies I), 20 percent horizontally stratified sandstone (facies G), 15 percent tabular crossstratified sandstone (facies F), 10 percent flaser, wavy, and lenticular bedded sandstone and mudstone (facies J), 5 percent structureless (bioturbated) mudstone (facies $\mathrm{K}$ ), and 5 percent dolomitic (stromatolitic) biostromes. Within the lower half of the deposit, some of the finer grained sandstones and mudstones show red to green mottling. This deposit also contains uncommon sets of tabular crossstratified sandstone, as thick as $1.5 \mathrm{~m}$, that are characterized by unimodal paleocurrent directions almost $180^{\circ}$ opposite to those of large-scale foresets in the underlying Gilbert-delta deposit. Several pelecypod-coquina beds are in the upper part of this paralic deposit. 


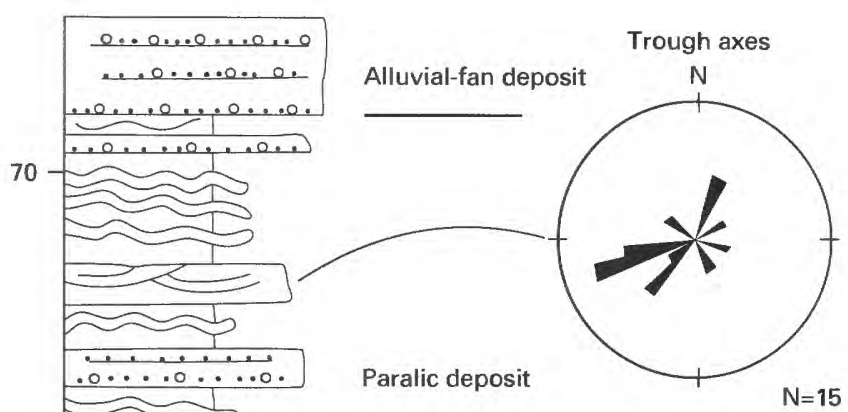

$\mathrm{N}=15$

60

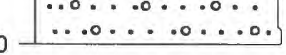

Alluvial-fan deposit

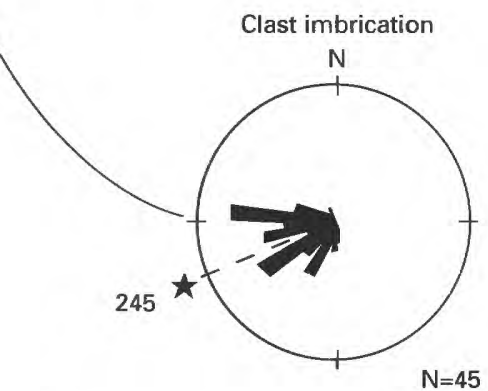

Figure 19. Paralic deposit lacking systematic grain-size trends. Paleocurrent vector mean listed next to star; $N$ is number of readings. Facies symbols explained on plate 1; location of section CMC2 $(62-71 \mathrm{~m})$ shown on plate 1 .

\section{Interpretation}

The paralic deposits probably accumulated in bay, lagoonal, intertidal, and supratidal or coastal-plain subenvironments. The diverse suite of physical and biogenic structures formed in response to a complex combination of fluvial discharge, waves, and tidal currents. These interacting processes resulted in fluctuating depositional energy and sediment supply.

The paralic deposit of section $\mathrm{CMC} 2$ records (1) cessation of alluvial-fan sedimentation, (2) sedimentation on a mud and sand tidal (supratidal) flat, and (3) reestablishment of alluvial-fan sedimentation. The mud and sand tidal flat was probably inundated only during periods of relatively high tides. A 1-m-thick bed of horizontal to low-angle stratified conglomeratic sandstone within the deposit probably records a flash flood that extended onto the supratidal flat from the distal margins of an alluvial fan. Holocene and Pleistocene tidal-flat deposits that intertongue with alluvial-fan deposits along the margins of the Gulf of California (Thompson, 1968) may provide a partial analogue for these deposits.

The paralic deposit of sections SMC1 and SMC2 records sedimentation during a relative rise of sea level. The ripple cross-laminated sandstone and horizontally stratified sandstone probably accumulated in a supratidal or coastal- plain setting. The red to green mottling of these sandstones is presumably related to early paleosol development. Overlying sets of tabular cross-stratified sandstone are interpreted as washover fans (Schwartz, 1982) deposited in a shallow lagoon during storm events. In addition, pelecypod shells were reworked into beds of coquina by tidal currents or by waves during storm events. During periods of low clastic influx, stromatolitic biostromes expanded laterally into intertidal and lagoonal subenvironments. This paralic deposit is truncated by a transgressive-shoreline deposit.

\section{Offshore-Marine Deposits}

\section{Description}

Nine offshore-marine deposits were recognized (plate 1). These deposits are from 2 to $170 \mathrm{~m}$ thick, have sheet geometry, and exhibit the greatest lateral continuity of any deposits in the study area. The base of the offshore-marine deposit forming the stratigraphic datum was traced laterally on aerial photographs for more than $10 \mathrm{~km}$. The basal bounding surfaces of these deposits with underlying transgressive-shoreline deposits are sharp and planar. The upper bounding surfaces are erosional or nonerosional and in either case generally planar. Offshore-marine deposits are gradationally overlain by either Gilbert-delta or shoreline deposits.

Offshore-marine deposits consist of sequences that either lack systematic grain-size trends or coarsen upward. Sequences that lack systematic grain-size trends consist of 80 percent laminated to structureless mudstone (facies $\mathrm{K}$ ), 15 percent dolomitic biostromes and bioherms, and 5 percent crudely stratified conglomeratic sandstone (facies B) or normally graded sandstone (facies C). In the southern and central Minturn cliffs (plate 1), the Lionshead Member contains biostromes as thick as $12 \mathrm{~m}$ and bioherms as thick as $15 \mathrm{~m}$ (Walker, 1972). The thickest (as much as $170 \mathrm{~m}$ ) bioherms are in the Wearyman Member (Walker, 1972) and crop out in the area of Two Elk Creek (plate 1). These bioherms exhibit either symmetrical mound-shaped or complex-mound-platform geometry.

Coarsening-upward sequences are characterized by an upward increase of structureless or crudely stratified conglomeratic sandstone (facies B) and structureless or normally graded sandstone (facies C). In general, sandstones comprise 10 percent facies $B$ and 90 percent facies $\mathbf{C}$.

Deformed intervals (4-15 $\mathrm{m}$ thick) of slump structures (fig. 21) are exposed in three offshore-marine deposits within road cuts of Interstate 70 (Karachewski, 1990). The slump folds and synsedimentary thrust faults generally exhibit a westerly vergence (plate 1).

Flute and groove casts on soles of sandstone beds also yield westerly paleocurrents (plate 1). Regional 

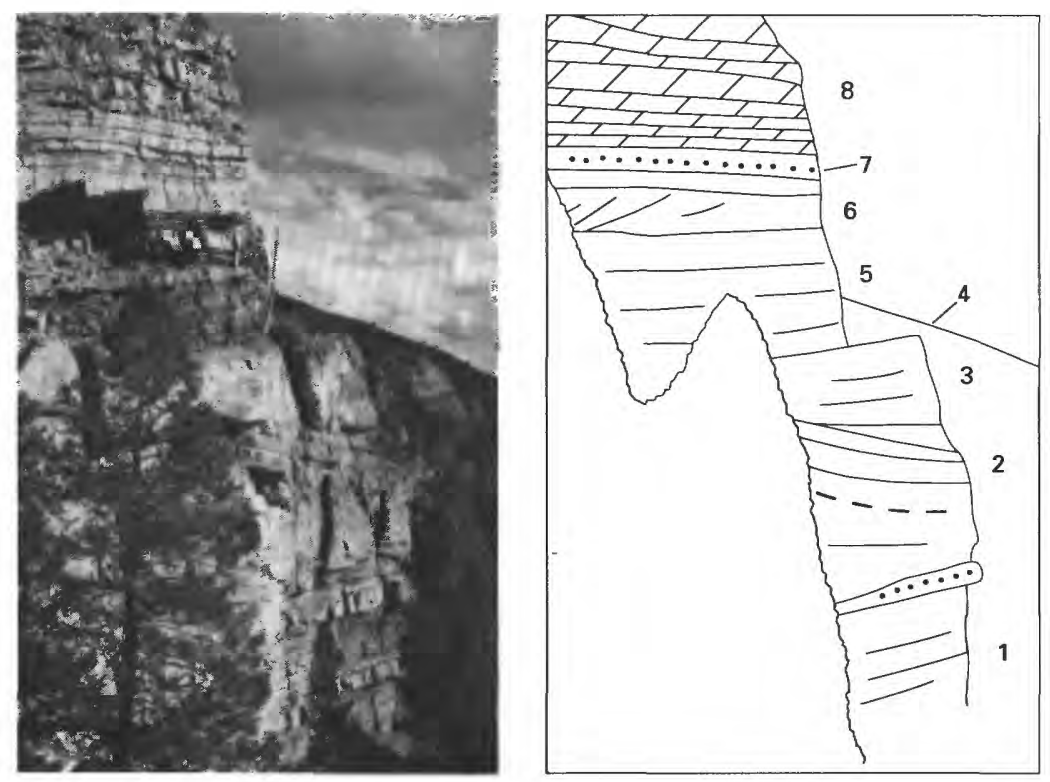

Figure 20. Paralic deposit (upper half) exhibiting a fining-upward sequence is correlative with but several hundred meters south of section SMC2 (99-111 m). Outcrop about $40 \mathrm{~m}$ high; location of section shown on plate 1. Description: 1, offshore-marine deposit; 2, Gilbert-delta deposit; 3, braidplain deposit; 4, sharp and nonerosional lower bounding surface of paralic deposit; 5, paralic deposit; 6, washover fan; 7, transgressive-shoreline deposit; 8 , offshore-marine deposit.

stratigraphic and paleogeographic reconstructions indicate that the Minturn Formation intertongues basinward (to the west) with the Eagle Valley Evaporite; however, evaporites were not recognized in offshore-marine deposits of this study.

\section{Interpretation}

Offshore-marine deposits accumulated in shallowshelf, bioherm-biostrome, and prodelta subenvironments. Sequences lacking systematic grain-size trends accumulated in a relatively distant setting from point sources of coarser grained siliciclastic detritus. In contrast, coarsening-upward sequences record progradation of either Gilbert deltas or regressive shorelines.

Plumes of suspended sediment were introduced into the water column during periods of high discharge to deltas and from large but infrequent storm events. During periods of low clastic influx, blue-green algae and Chaetetes colonies expanded laterally into biostromes and vertically into bioherms. Walker (1972) suggested that many of the biostromes and bioherms in the Minturn developed in relatively shallow water near the toes of deltas and alluvial fans. Hayward (1985) noted the presence of modern coralline reefs in close proximity to coastal alluvial fans of the Red Sea; some of the Minturn bioherms probably developed in a similar geomorphic setting. The thick bioherms indicate that algal growth was capable of keeping pace with relative rises in sea level. This inference is particularly impressive for the interval containing the 170-m-thick Wearyman bioherm.

Most submarine slumps in the Minturn Formation were probably triggered by a combination of rapid deposition on oversteepened slopes and earthquake activity. Seismicity in the area is attributed to movement on the range-bounding Gore fault, located about $12 \mathrm{~km}$ to the northeast of the study area.

\section{GENETIC SEQUENCES}

Genetic sequences are generally bounded by transgressive surfaces of erosion, although they locally may be defined by paralic flooding surfaces. Bounding surfaces are assumed to be isochronous throughout the small study area $\left(25 \mathrm{~km}^{2}\right)$ because they are laterally continuous and they separate strata deposited in older and more landward environments from strata deposited in younger and more basinal environments. Genetic sequences are asymmetric and made up of thin transgressive and thick regressive units. Genetic sequences are similar to punctuated aggradational cycles (Goodwin and Anderson, 1985) or parasequences (Van Wagoner and others, 1988). The approach just described differs from the methodology of Mitchum, Vail, 

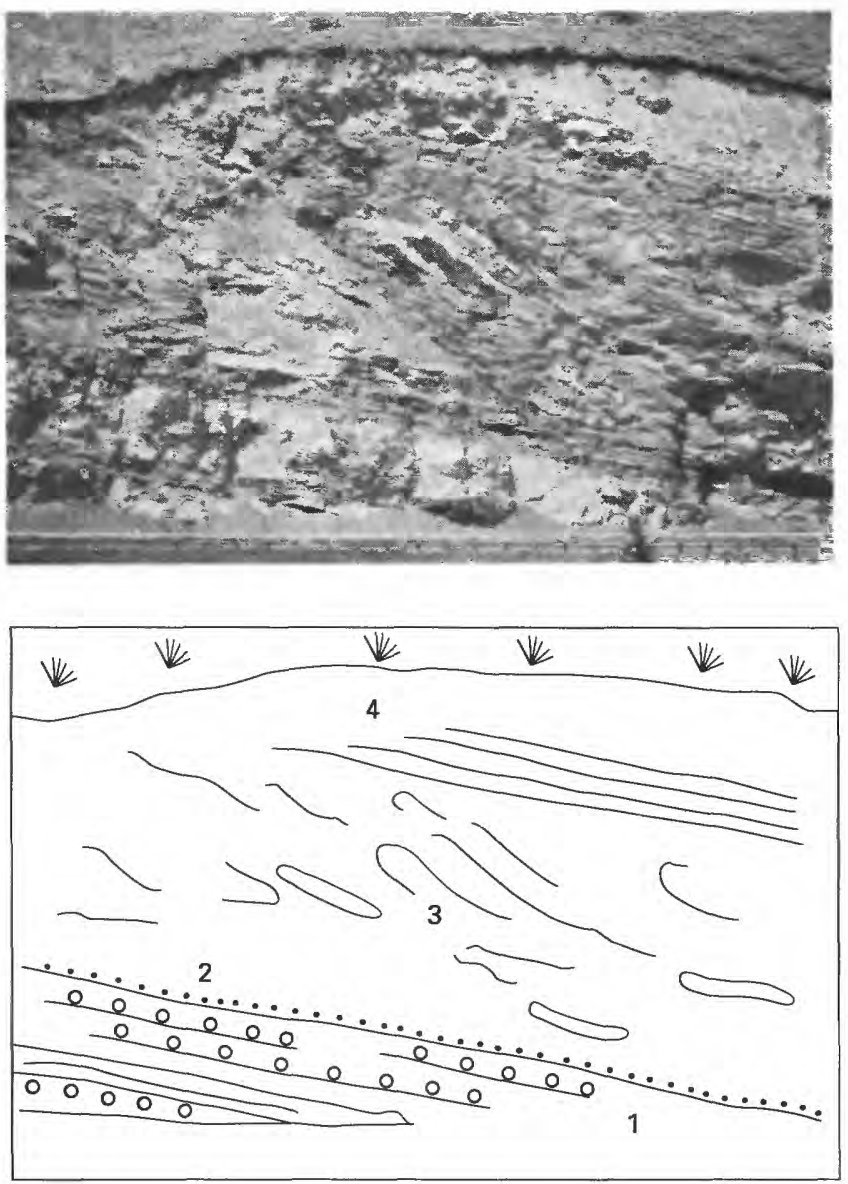

Figure 21. Relatively undeformed strata, synsedimentary thrust faults, slump folds, and detached blocks of sandstone. Road cut oriented almost perpendicular to the apparent direction of paleoslope. Section DJ3 (310-325 m); road cut about $20 \mathrm{~m}$ high. In 1989, the appearance of this road cut was significantly altered by a construction project designed to reduce the rockfall hazard. Location of section shown on plate 1. Description: 1, alluvial-fan deposit; 2 , transgressive surface of erosion and shoreline deposit; 3 , slump folds and detached sandstone blocks developed in offshore-marine deposit; 4, undeformed offshore-marine deposit.

and Thompson (1977); their sequences are bounded by interregional unconformities or correlative conformities.

\section{Methods of Correlation}

The stratigraphic datum for correlation is a distinct contact between alluvial-fan deposits at the top of clastic unit $\mathrm{D}$ and offshore-marine deposits at the base of clastic unit $E$ (fig. 22). Twelve genetic sequences (fig. 23) were recognized in clastic units B (uppermost part), C, and D of Tweto and Lovering (1977). Because of the difficulty of correlating some genetic sequences, a number-letter scheme was used; for example, genetic sequences $8 \mathrm{~A}, 8 \mathrm{~B}, 8 \mathrm{C}$, and $8 \mathrm{D}$ in section $\mathrm{NMC1}$ are correlative with genetic sequence 8 in section NMC2. Because clastic units A and B of Tweto and Lovering (1977) were examined in reconnaissance, genetic sequences in the basal Minturn Formation near Rock Creek are numbered $\mathrm{RC} 1, \mathrm{RC} 2$, and so on.

To explain the apparent differences in the number of genetic sequences between adjacent stratigraphic sections, three hypothetical examples are discussed. In the first example (fig. 24A), measured section I contains one genetic sequence, whereas measured section II contains two genetic sequences. This discrepancy is attributed to subaerial exposure and nondeposition between points $e$ and $f$ and valley incision and fill by alluvial-fan or braidplain deposits between points $f$ and $g$. A genetic sequence boundary could be recognized at point $e$ if the mudstone (1) showed evidence of subaerial exposure (such as paleosol development) and (or) (2) was overlain by a condensed section. Because mudstones typically form poor outcrops, recognition of these surfaces would be difficult. This example is based on genetic sequence $8 \mathrm{C}$ in section DJ3 (plate 1).

In the second example (fig. 24B), measured section I contains one genetic sequence, whereas measured section II contains two genetic sequences. This discrepancy is attributed to erosional truncation of offshore-marine or paralic deposits between points $r$ and $s$. It would be difficult to recognize a genetic sequence boundary within alluvialfan or braidplain deposits because most beds are bounded by erosional surfaces. This example is based on genetic sequences $10,10 \mathrm{~A}$, and $10 \mathrm{~B}$ in section $\mathrm{CMC} 2$ and genetic sequence 10 in section SMC2 (plate 1).

In the third example (fig. 24C), measured section I contains two genetic sequences, whereas measured section II contains three genetic sequences, although the uppermost regressive unit is not shown. This discrepancy is attributed to variable progradation of Gilbert deltas. If a condensed

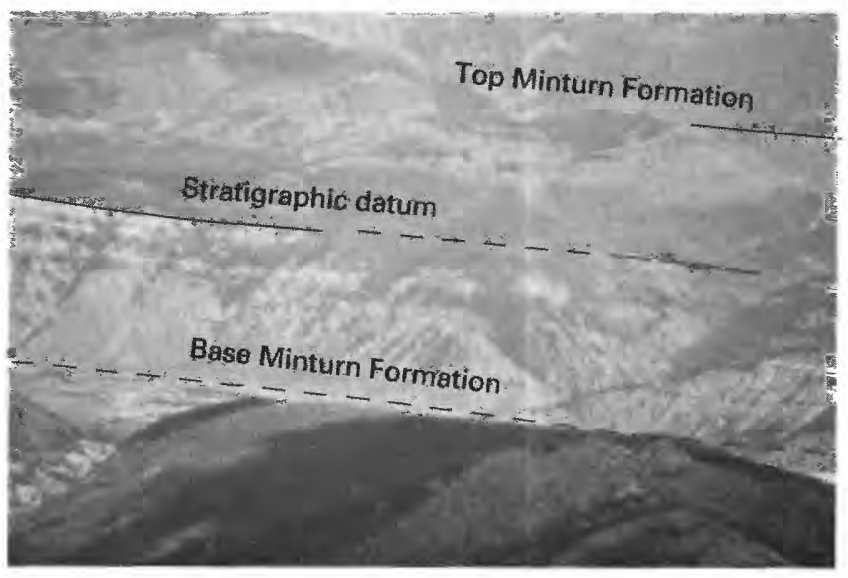

Figure 22. Aerial photograph showing stratigraphic datum in vicinity of central and southern Minturn cliffs. The datum is topographically distinct because it separates cliff-forming alluvial-fan deposits from overlying slope-forming offshoremarine deposits. The apparent offset of the datum is attributed to topography and the oblique angle of the photograph. 


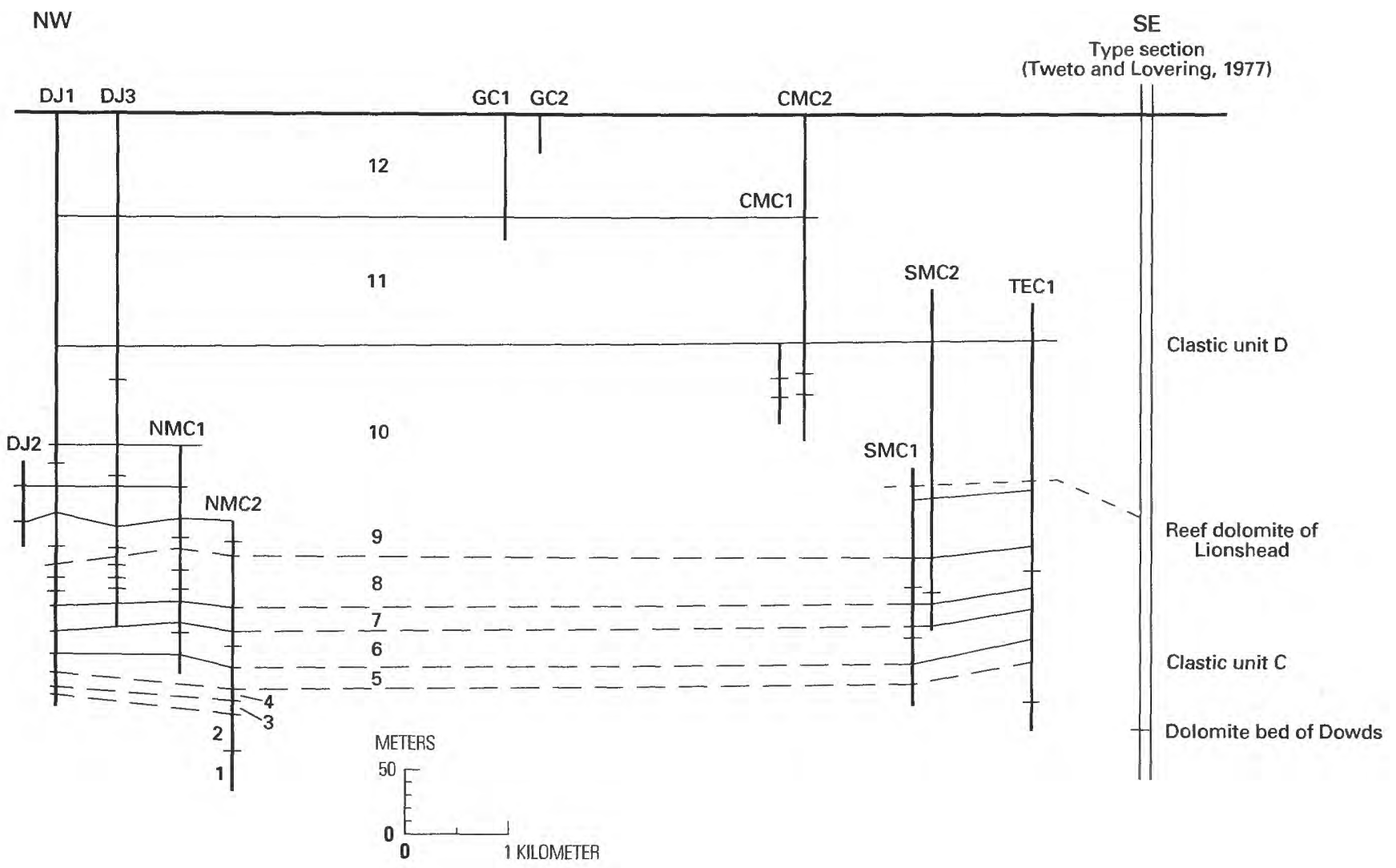

Figure 23. Generalized cross section, oriented subparallel with inferred depositional strike, showing correlation and thickness of genetic sequences (numbered). Dashed lines indicate tentative correlations. Modified from plate 1; locations of measured sections shown on plate 1 .

section were recognized at point $x$, a genetic sequence boundary could be carried through the mudstone interval. This example is based on distribution of Gilbert deltas near Two Elk Creek (plate 1).

\section{Characteristics of Genetic Sequences}

Genetic sequences exhibit two types of transgressive units and two types of regressive units (fig. 25). Transgressive units are generally composed of a transgressive surface of erosion and thin (less than $10 \mathrm{~cm}$ ), laterally discontinuous transgressive-shoreline deposits. The thickest transgressive unit is in section SMC2 (84-110 $\mathrm{m}$ ) and consists of a deepening-upward succession of paralic to transgressive-shoreline and offshore-marine deposits. Ideally, transgressive and regressive units are separated by a condensed section; however, condensed sections are not obvious in the Minturn Formation and may not be present because of rapid rates of sedimentation near the ancestral Front Range. Gradational regressive units shoal upward from offshore-marine or paralic (bay) deposits into Gilbert-delta (fig. 16) or shoreline deposits (fig. 18). In contrast, nongradational regressive units (fig. 26) consist of offshore-marine or paralic (bay) deposits, a regressive surface of erosion, and overlying alluvial-fan or braidplain deposits. About 75 percent of the genetic sequences contain nongradational regressive units, whereas only about 25 percent of the genetic sequences contain gradational regressive units.

\section{Lateral Relationships Between Sedimentary Environments Within a Genetic Sequence}

Plate 1 shows the lateral relationships between sedimentary environments within genetic sequences in a cross sectional view oriented subparallel with the inferred Middle Pennsylvanian depositional strike. The lateral relationships between sedimentary environments within genetic sequence 7 (fig. 27) are discussed because the sequence contains both gradational and nongradational regressive units.

Genetic sequence 7 has a uniform thickness of $18 \mathrm{~m}$ from the Dowds Junction to the Two Elk Creek measured section (plate 1), a distance of about $7 \mathrm{~km}$. At Dowds Junction, the transgressive surface of erosion is overlain by offshore-marine deposits that shoal upward to shoreline 

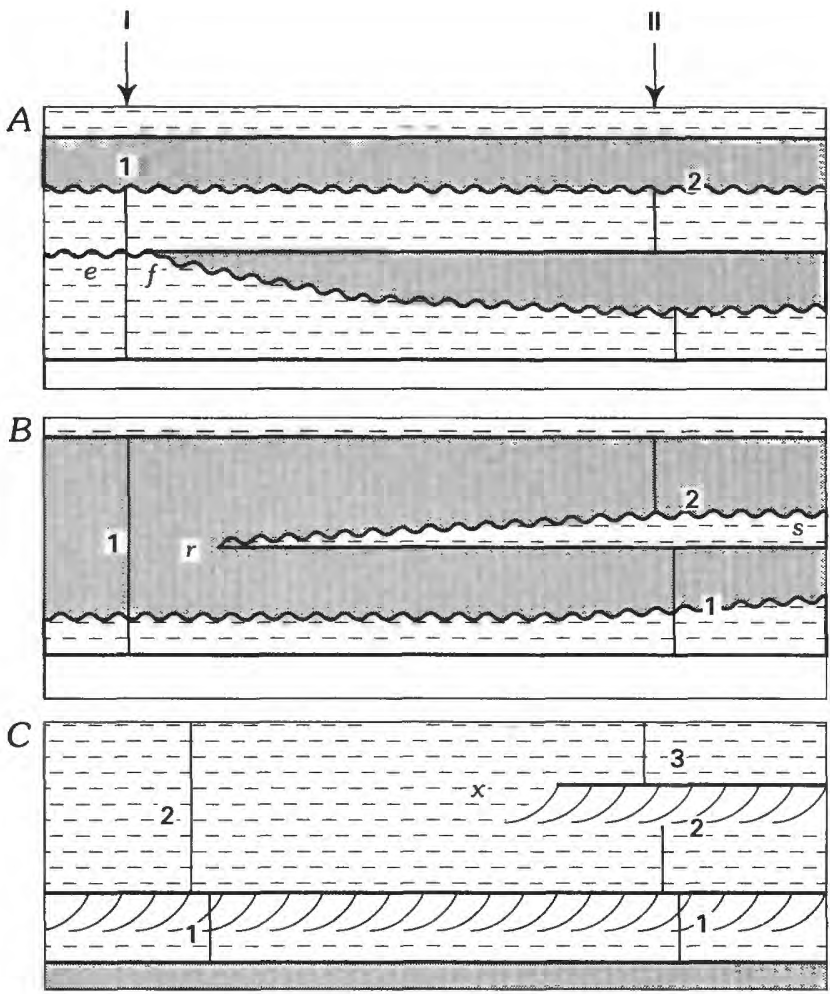

EXPLANATION

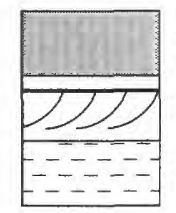

Alluvial-fan or braidplain deposit

Gilbert-type delta deposit

Offshore-marine or paralic deposit

Flooding surface

$\sim \sim$ Erosional surface

Figure 24. Illustrations of the apparent difference in the number of genetic sequences between adjacent measured sections (I and II). Italicized letters are reference points for discussion in text.

deposits. At Two Elk Creek, offshore-marine deposits grade laterally to paralic (bay or lagoonal) deposits that are truncated by a regressive surface of erosion and overlain by braidplain deposits.

I am uncertain whether regressive surfaces of erosion within genetic sequences are of local or regional extent. If these surfaces are of local extent, they probably result from avulsion of a braidplain or progradation of an alluvial fan into a paralic or shoreline setting. Thompson (1968) described modern geomorphic analogues for this scenario from Baja California. If these surfaces are of regional extent, they are probably related to lowering of relative sea level. This lowering resulted in steeper coastal gradients, which led to erosional truncation of underlying gradational regressive units such as Gilbert-delta or shoreline deposits. A subsequent relative rise of sea level would have juxtaposed erosionally truncated marine or paralic deposits with aggrading alluvial-fan or braidplain deposits.

\section{Vertical Stacking Patterns of Genetic Sequences}

In general, genetic sequences within the lower Minturn Formation exhibit a thickening-upward trend (fig. 28, plate 1). Genetic sequences 1 through 9 are commonly $10-20 \mathrm{~m}$ thick, although they range in thickness from 6 to $45 \mathrm{~m}$. The thickness of genetic sequence 10 is less certain because of tentative correlations. In section TEC1, genetic sequence 10 is $120 \mathrm{~m}$ thick. In section DJ3, this same interval contains as many as five genetic sequences, which are from 10 to $76 \mathrm{~m}$ thick. Genetic sequences 11 and 12 are about $100 \mathrm{~m}$ and $80 \mathrm{~m}$ thick, respectively.

Genetic sequences 1 through 8 are primarily composed of paralic and braidplain deposits; offshoremarine and shoreline deposits are present but uncommon. Genetic sequence 9 is composed of offshore-marine, Gilbert-delta, paralic, and braidplain deposits. Genetic sequences 10,11 , and 12 contain offshore-marine, alluvialfan, and minor paralic deposits. Alluvial-fan deposits of genetic sequences 10,11 , and 12 ("grit marker bed" of Tweto and Lovering, 1977) comprise the thickest and coarsest conglomeratic sandstones in the Minturn-Vail area.

\section{Controls on Development of Genetic Sequences}

On a basinwide scale, thick (as much as $5,000 \mathrm{~m}$ ) Pennsylvanian and Permian sedimentary rocks of the Eagle basin (De Voto and others, 1986) are the depositional product of ancestral Rocky Mountain tectonism. The tectonic component (subsidence and uplift) operated on long $\left(10^{6}-10^{7}\right.$ years), intermediate $\left(10^{5}-10^{6}\right.$ years), and short $\left(1-10^{5}\right.$ years) time intervals. Long-term subsidence influenced the thickness of sedimentary rocks throughout the basin (De Voto and others, 1986) but was too slow to explain the high frequency of Minturn genetic sequences. The thickening-upward trend of genetic sequences 1 through 12 is attributed to uplift of the ancestral Front Range and (or) subsidence of the Eagle basin on an intermediate-time scale. Short-term seismic activity and faulting having several meters of vertical displacement could produce a tectonic transgression (Leeder, 1988) and flooding of the coastal plain.

Assuming a constant rate of subsidence and eustasy, genetic sequences may be produced by fluctuations in sediment supply. During times of low sediment input, subsidence predominates and transgressions ensue. High sediment input results in regression or progradation. Schumm (1977) attributed variation in sediment supply to 
$\underline{A}$

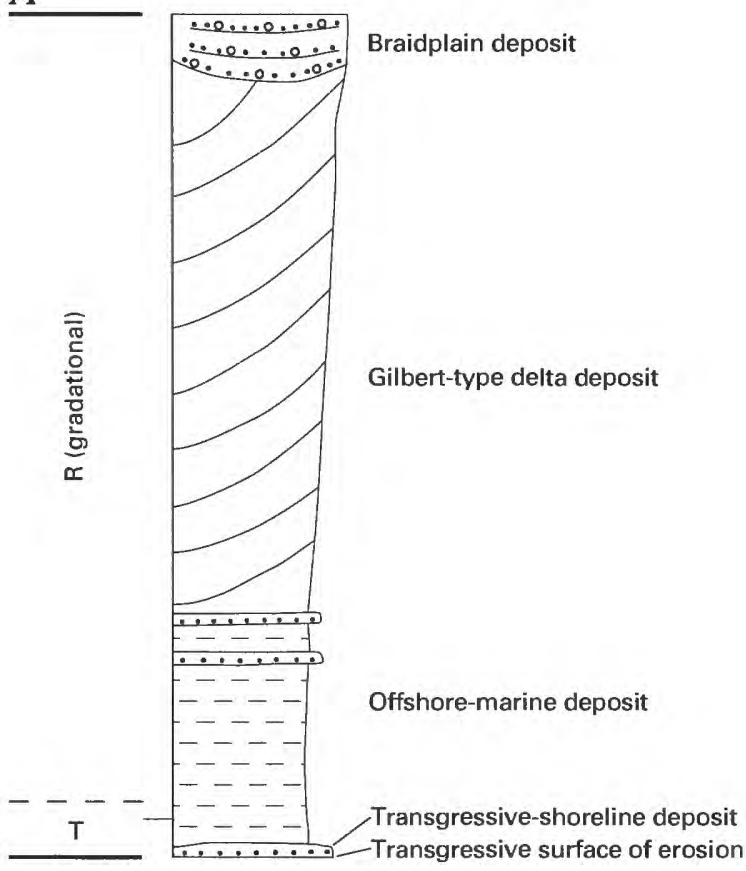

$\underline{B}$

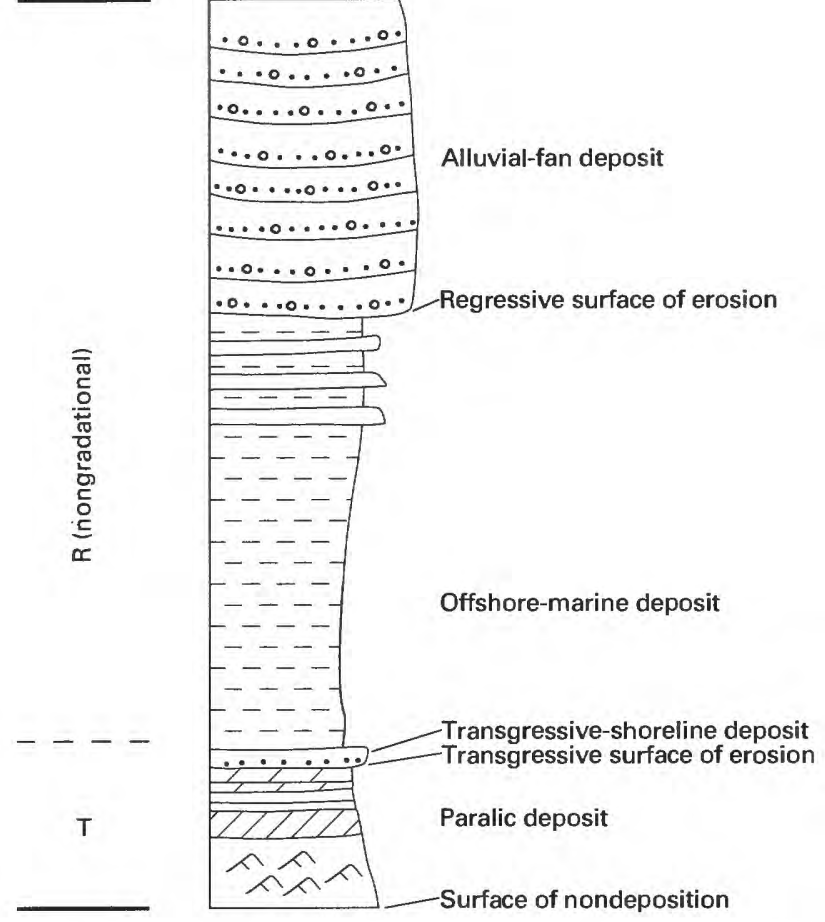

Figure 25. Two examples of variability in transgressive $(T)$ and regressive $(R)$ units within a genetic sequence. Location of section shown on plate 1. A, Genetic sequence 9 of section SMC2 consists of a thin transgressive unit and a gradational regressive unit. $B$, Genetic sequence 10 of section SMC2 consists of a thicker transgressive unit and a nongradational regressive unit.

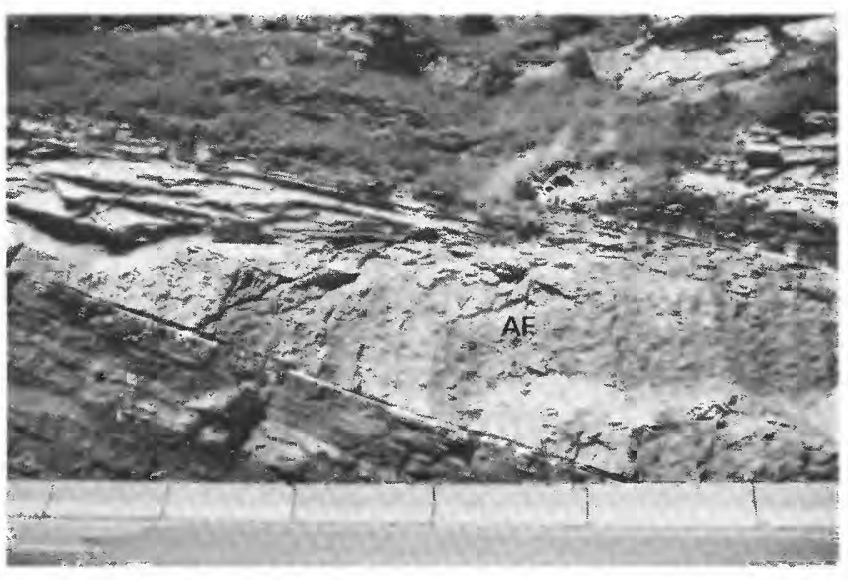

Figure 26. Genetic sequence $10 \mathrm{~A}$ of section DJ3 is bounded by transgressive surfaces of erosion (TSE) and consists of a paralic $(P)$ deposit, regressive surface of erosion (RSE), and alluvial-fan (AF) deposit. Transgressive surface of erosion at base of sequence is just out of view at lower left corner.

source and basin relief and climate. Changing climate may result in short-term pulses of sediment influx (Galloway, 1989). As an example, Hite and others (1984) proposed that influx of siliciclastic detritus and evaporite sedimentation in the Paradox basin was controlled by Pennsylvanian climate changes in synchroneity with glacio-eustatic sea-level

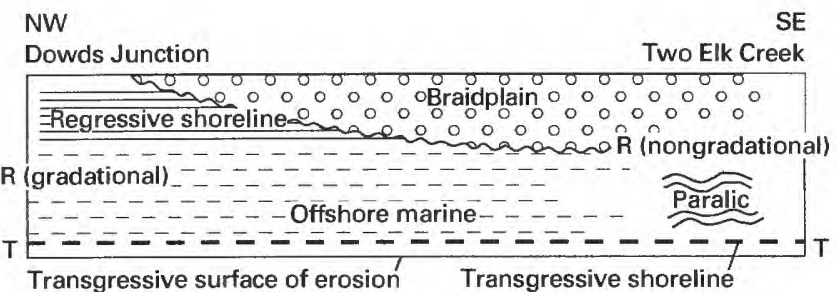

Figure 27. Generalized distribution of sedimentary environments within genetic sequence $7 . R$ and $T$ refer to regressive and transgressive units, respectively. Not drawn to scale. Locations of Dowds Junction and Two Elk Creek measured sections shown on plate 1.

changes. In their model, the basinward influx of siliciclastic detritus was greatest during the more arid periods because the loss of vegetative cover accelerated erosion rates in source areas.

Although tectonism and sediment supply were important variables influencing development of Minturn genetic sequences, glacio-eustasy was probably the most important mechanism. Waxing and waning of Gondwanan glaciers (Crowell, 1978) is an attractive mechanism to explain repetitive,' high-frequency changes in base level. These changes were mainly responsible for the abrupt stacking of marine and nonmarine deposits between, and within, genetic sequences. Furthermore, the 


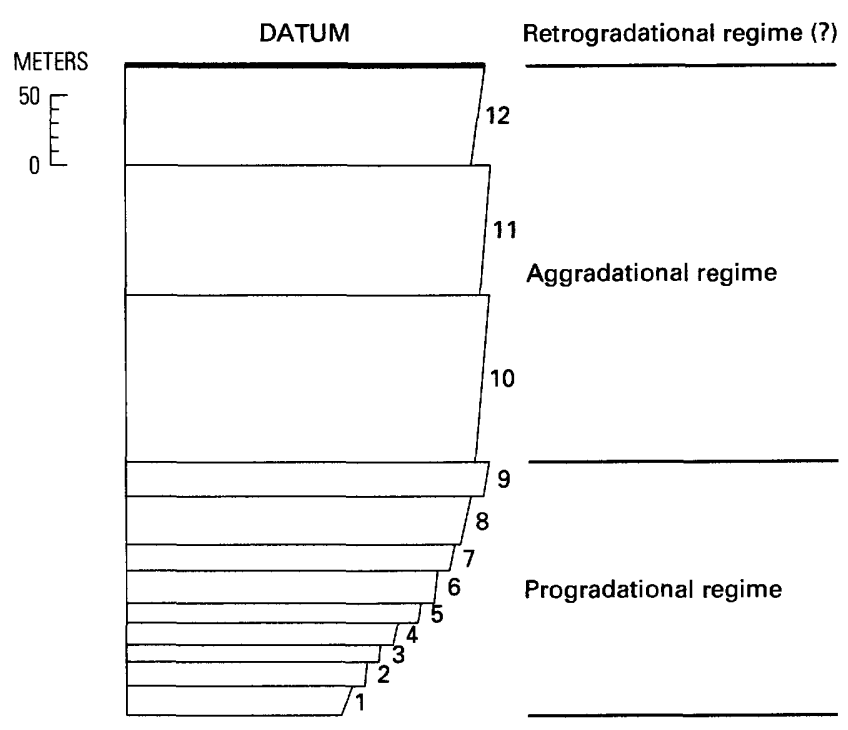

Landward

Seaward

Figure 28. Vertical stacking patterns of genetic sequences 1 through 12. Base of each genetic sequence reflects relative landward versus seaward position with respect to underlying genetic sequence.

100,000-400,000-year periodicity of Minturn (Karachewski, 1990), Morgan (Driese and Dott, 1984), Eagle Valley (Schenk, 1989), Paradox (Hite and others, 1984), and midcontinent (Heckel, 1986) cycles corresponds to the eccentricity cycle of the Milankovitch theory. Pleisto- cene glaciations provide support for the temporal correlation between the advance and retreat of glacial ice and the effects on worldwide sea level (Evans, 1979; Imbrie and Imbrie, 1980).

\section{PALEOGEOGRAPHY}

The paleogeography of genetic sequences RC4,6A, 9 (9A), and 12 (plate 1) is discussed below. Paleogeographic maps were constructed for time lines near the base and top of each genetic sequence. The first map of each pair shows the inferred extent of maximum flooding, whereas the second map shows the inferred extent of maximum progradation. The modern Gore fault is shown on each map, although the fault that bounded the ancestral Front Range uplift may have been several kilometers northeast of the Gore fault.

The inferred paleogeography of genetic sequence $\mathrm{RC} 4$ is shown in figure 29. A relative rise of sea level resulted in flooding of the study area and deposition of mudstone in paralic (bay or estuarine) environments. During maximum flooding, shoreline and paralic (coastal plain) sedimentation was restricted to a narrow tract near the ancestral Front Range uplift. During a sea-level stillstand or slowly falling sea level, shoreline and paralic (coastal plain) environments prograded, and the coastal plain was probably traversed by small meandering (?) streams.
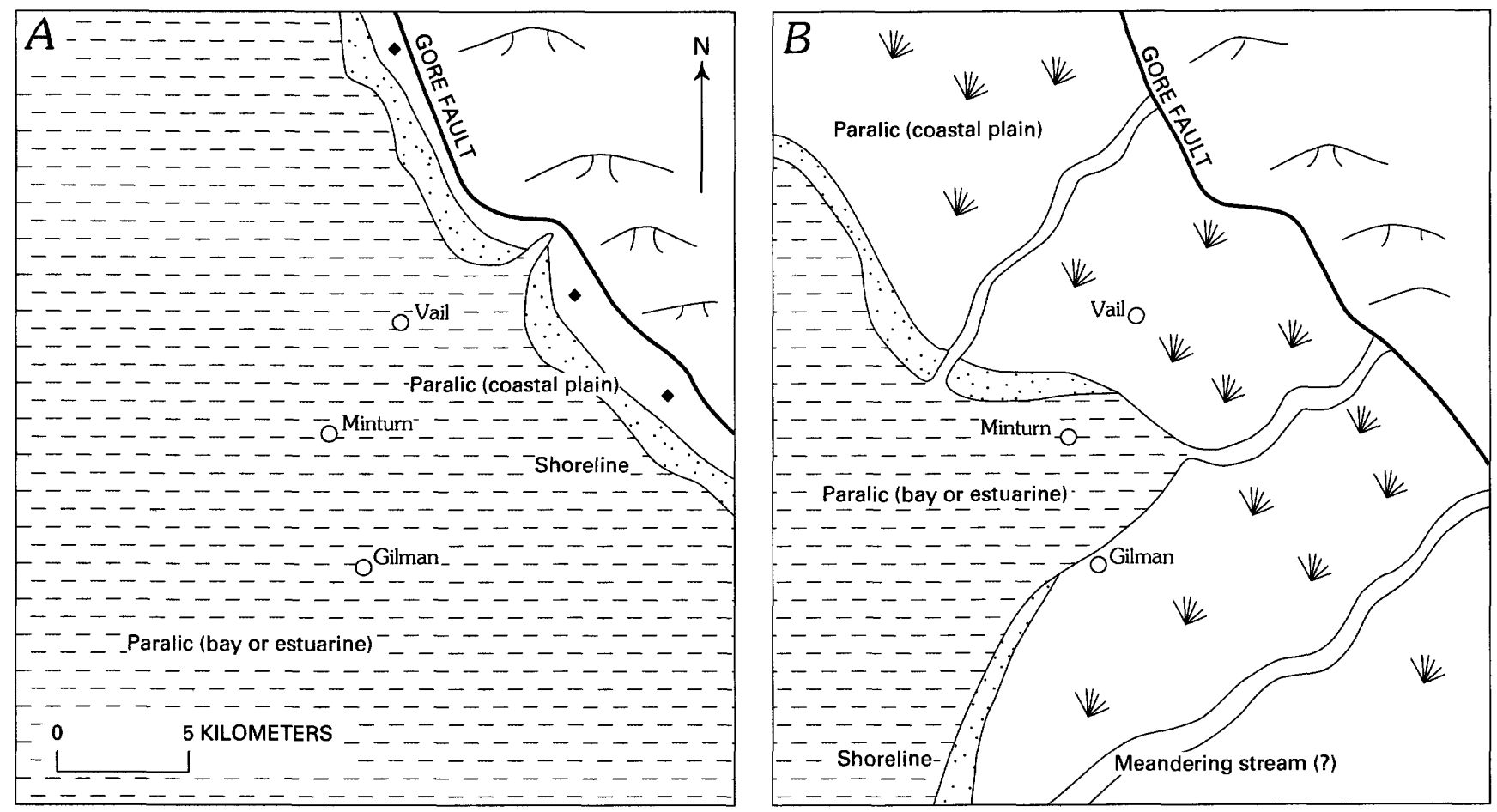

Figure 29. Inferred paleogeography for genetic sequence RC4 during periods of $(A)$ maximum flooding and $(B)$ maximum progradation. 

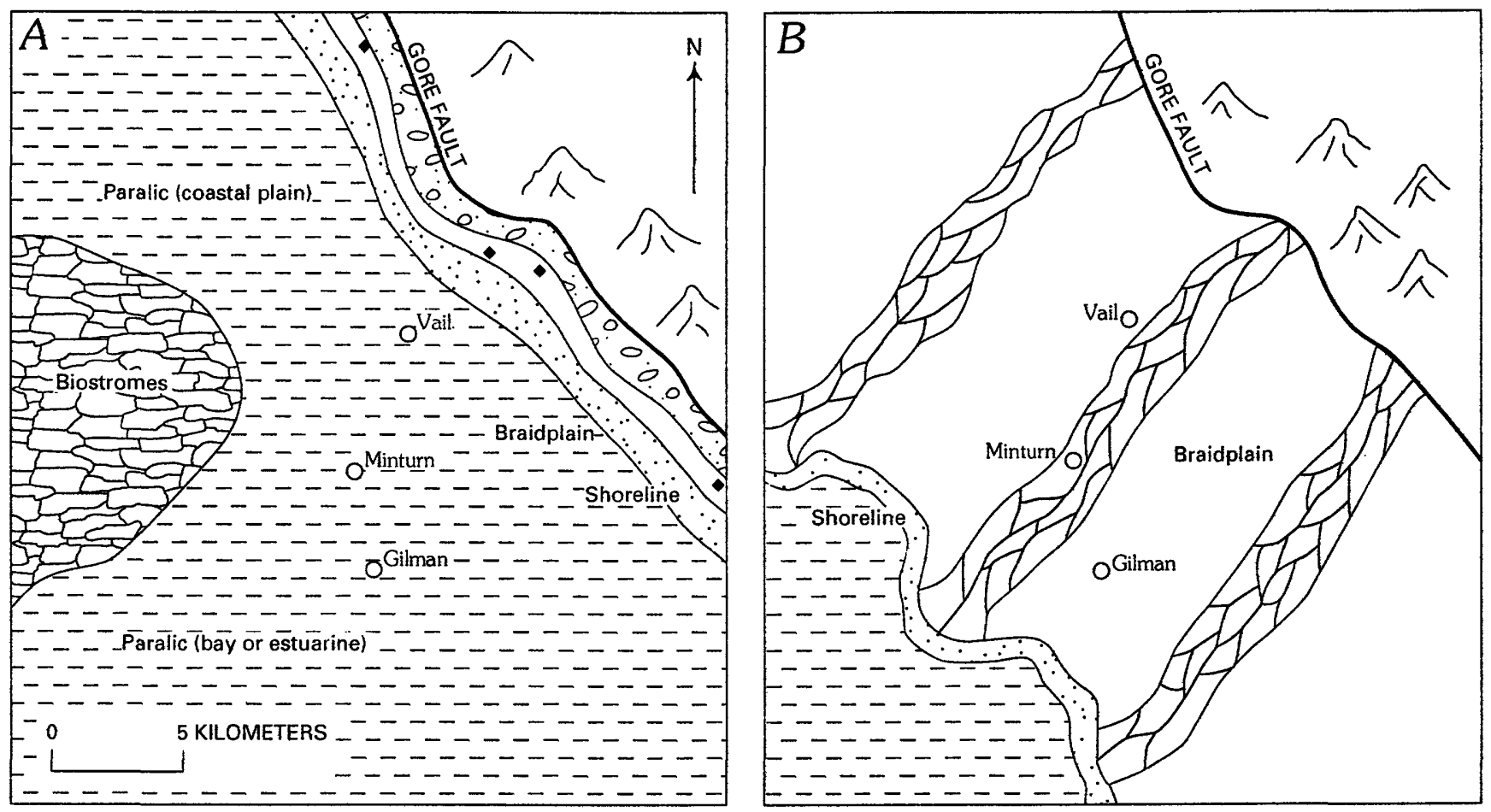

Figure 30. Inferred paleogeography for genetic sequence $6 \mathrm{~A}$ during period of $(A)$ maximum flooding and $(B)$ maximum progradation.
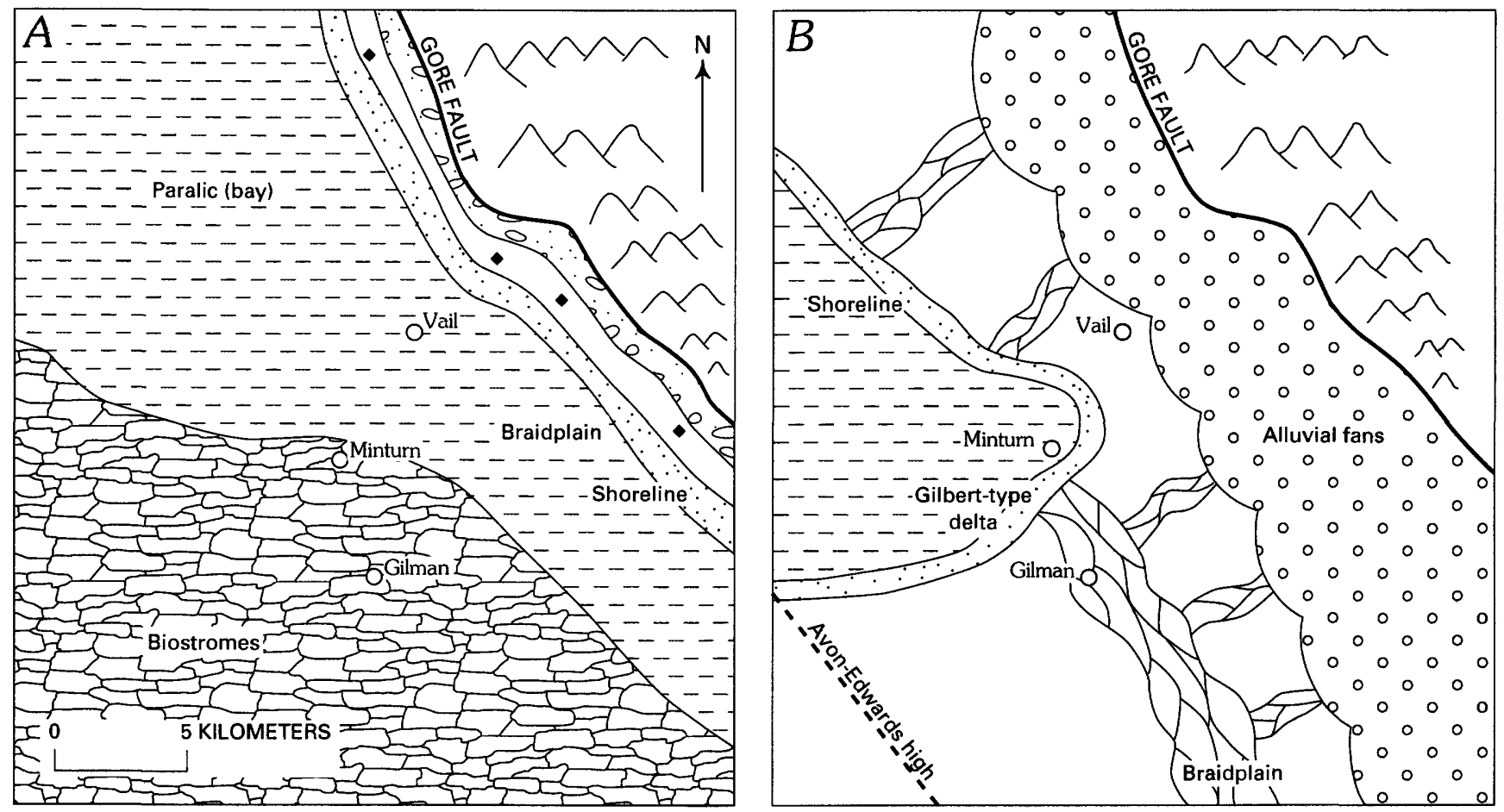

Figure 31. Inferred paleogeography for genetic sequences 9 and $9 A$ during period of $(A)$ maximum flooding and $(B)$ maximum progradation.

The inferred paleogeography of genetic sequence $6 \mathrm{~A}$ is shown in figure 30 . A relative rise of sea level resulted in flooding of the study area and deposition of mudstone in paralic (bay or estuarine) environments. In addition, bluegreen algal biostromes flourished in west-central parts of the study area. During maximum flooding, shoreline, 

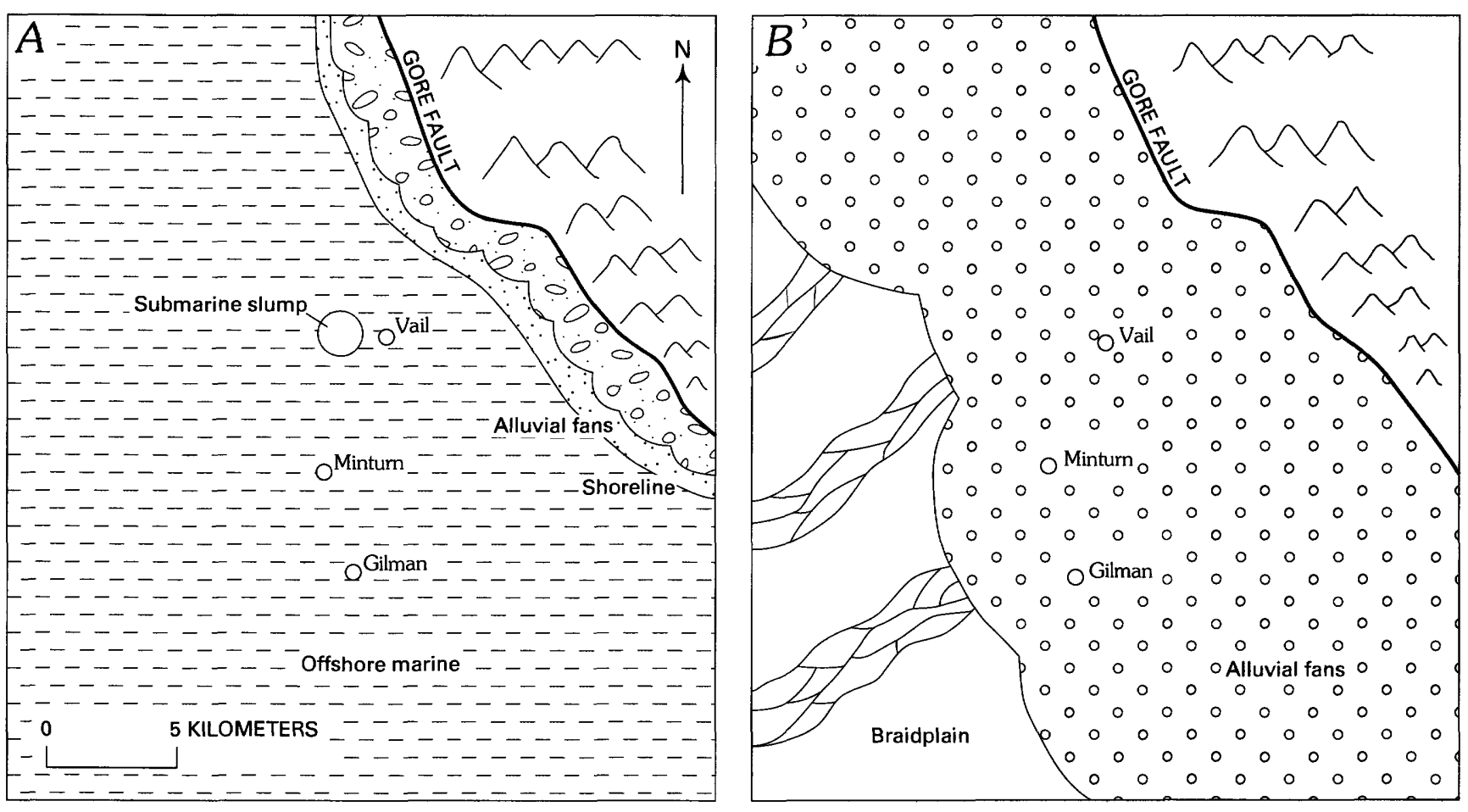

Figure 32. Inferred paleogeography for genetic sequence 12 during period of $(A)$ maximum flooding and $(B)$ maximum progradation.

paralic (coastal plain), and braidplain sedimentation was restricted to a narrow tract near the ancestral Front Range uplift. A relative drop of sea level resulted in valley incision and erosional truncation of paralic (bay, estuarine, coastal plain) and shoreline deposits. A subsequent relative rise of sea level resulted in aggradation of braidplain deposits.

The uncertain correlation between genetic sequences 9 and 9A hinders paleogeographic reconstructions. The inferred paleogeography for these sequences is shown in figure 31 .

A relative rise of sea level resulted in flooding of the study area and deposition of mudstone in offshore-marine or paralic (bay) environments. In addition, blue-green algal biostromes flourished in the southwestern part of the study area. During maximum flooding, shoreline, paralic (intertidal or supratidal), and braidplain sedimentation was restricted to a narrow tract near the ancestral Front Range uplift. Under conditions of relatively stable or slowly falling sea level, the Gilbert delta of sections TEC1, SMC1, and SMC2 prograded toward the north into water about $15 \mathrm{~m}$ deep. Based on this trend, one would expect deeper water and offshore-marine deposits toward the northwest. Genetic sequence 9A of sections NMC1, NMC2, DJ3, and DJ1 comprises offshore-marine deposits, but the overlying Gilbert delta prograded into water only about $3 \mathrm{~m}$ deep. These observations indicate that Gilbert deltas prograded into variable water depths. The northerly trend of Gilbert deltas is anomalous in that paleocurrent analysis of all other deposits yields a westerly to southwesterly paleoslope. This northerly trend is attributed to development of a longitudinal (basin axis) fluvial system that probably reflects structural uplift on the Avon-Edwards high (Schenk, 1989), a northern extension of the ancestral Sawatch uplift.

The inferred paleogeography of genetic sequence 12 is shown in figure 32. A relative rise of sea level resulted in flooding of the study area and deposition of mudstone and minor sandstone in offshore-marine environments. Contemporaneous with deposition, some of the deposits in section DJ3 (310-325 m) were involved in slumping. Fold axes from slump folds suggest an apparent (because of two-dimensional road cut) northwesterly paleoslope. During maximum flooding, shoreline and alluvial-fan sedimentation was restricted to a narrow tract near the ancestral Front Range uplift. A relative drop of sea level resulted in valley incision and erosional truncation of offshore-marine and shoreline deposits. A subsequent relative rise of sea level resulted in aggradation of alluvialfan deposits. Within alluvial-fan deposits, clast imbrication suggests a southwesterly paleoslope.

Previous paleogeographic reconstructions of the upper Minturn Formation in the Minturn-Vail area were based primarily on facies trends of carbonate rocks (Boggs, 1966; Tillman, 1971; Walker, 1972). These reconstructions suggest that the depositional basin (Vail-McCoy trough) was asymmetric; deeper water and greater subsidence rates 
were along the landward margin of the basin, and shallower water and slower subsidence rates were toward the center of the basin. Shoaling conditions toward the center of the basin were attributed to a structural high or platform, which De Voto (1972) named the ancestral Sawatch uplift. Schenk (1989) concurred with these paleogeographic reconstructions, although he named this small intrabasin uplift the Avon-Edwards high. Paleocurrent analysis associated with my study demonstrates that siliciclastic detritus of the lower Minturn Formation was derived from the ancestral Front Range uplift and that the paleoslope was toward the west or southwest. Although the Avon-Edwards high may have influenced development of a basin-axis fluvial system, it was probably of low topographic relief because it did not shed siliciclastic sediment toward the northeast into the depositional area of the lower Minturn Formation.

\section{CONCLUSIONS}

Siliciclastic and minor carbonate rocks of the lower part of the Minturn Formation were deposited in alluvialfan, braidplain, Gilbert-delta, shoreline, paralic, and offshore-marine environments. Twelve genetic sequences, defined as paired transgressive-regressive units, were recognized within clastic units B (uppermost part), C, and D of Tweto and Lovering (1977). The sequences are generally asymmetric and composed of thin transgressive units and thick regressive units. Regressive units are subdivided into gradational (25 percent) and nongradational (75 percent) types. Gradational regressive units formed by progradation of shorelines or Gilbert deltas during relative sea-level stillstands. Within nongradational regressive units, the erosional juxtaposition of marine or paralic deposits with overlying alluvial-fan or braidplain deposits records either autocyclic or allocyclic processes. The thickening-upward trend of genetic sequences and the stacking of alluvial-fan deposits in the uppermost genetic sequences are attributed to an increase in tectonic activity. Waxing and waning of Gondwana glaciers is an attractive mechanism to explain the repetitive, high-frequency, base-level changes associated with nongradational regressive units.

Paleocurrent analysis indicates that regional paleoslope was toward the west or southwest and that siliciclastic detritus was derived from the ancestral Front Range uplift. The north to northwest trend of Gilbert deltas may be related to structural activity on the Avon-Edwards high at the northern end of the ancestral Sawatch uplift, activity that resulted in development of a longitudinal or basin-axis drainage pattern.

\section{REFERENCES CITED}

Aitken, J.D., 1967, Classification and environmental significance of cryptalgal limestones and dolomites, with illustrations from the Cambrian and Ordovician of southwestern Alberta: Journal of Sedimentary Petrology, v. 37, p. 1163-1178.

Allen, J.R.L., 1968, Current ripples-Their relation to patterns of water and sediment motion: Amsterdam, North-Holland Publishing, $433 \mathrm{p}$.

Anderton, R., 1985, Clastic facies models and facies analysis, in Brenchley, P.J., and Williams, B.P.J., eds., Sedimentology-Recent developments and spatial aspects: Oxford, Blackwell Scientific Publications, p. 31-46.

Bergendahl, M.H., and Koschmann, A.H., 1971, Ore deposits of the Kokomo-Tenmile district, Colorado: U.S. Geological Survey Professional Paper 652, $53 \mathrm{p}$.

Blatt, H., Middleton, G., and Murray, R., 1980, Origin of sedimentary rocks: Englewood Cliffs, Prentice-Hall, 782 p.

Boggs, S., Jr., 1966, Petrology of the Minturn Formation, eastcentral Eagle County, Colorado: American Association of Petroleum Geologists Bulletin, v. 50, p. 1399-1422.

Bouma, A.H., 1962, Sedimentology of some flysch deposits: Amsterdam, Elsevier, 168 p.

Bruun, P., 1962, Sea level rise as a cause of shore erosion: Journal of Waterways and Harbors Division, American Society of Civil Engineers, Proceedings, v. 88, p. 117-130.

Bull, W.B., 1977, The alluvial-fan environment: Progress in Physical Geography, v. 1, p. 222-270.

Clemmensen, L.B., and Houmark-Nielsen, M., 1981, Sedimentary features of a Weichselian glaciolacustrine delta: Boreas, v. 10, p. 231-245.

Clifton, H.E., 1973, Pebble segregation and bed lenticularity in wave-worked versus alluvial gravel: Sedimentology, v. 20, p. 173-187.

Colella, A., 1988, Pliocene-Holocene fan deltas and braid deltas in the Crati basin, southern Italy-A consequence of varying tectonic conditions, in Nemec, W., and Steel, R.J., eds., Fan deltas-Sedimentology and tectonic setting: Glasgow and London, Blackie and Son, p. 50-74.

Collinson, J.D., 1986, Alluvial sediments, in Reading, H.G., ed., Sedimentary environments and facies (2nd ed.): Oxford, Blackwell Scientific Publications, p. 20-62.

Collinson, J.D., and Thompson, D.B., 1982, Sedimentary structures: London, George Allen and Unwin, 194 p.

Crowell, J.C., 1978, Gondwana glaciation, cyclothems, continental positioning, and climate change: American Journal of Science, v. 278, p. 1345-1372.

De Voto, R.H., 1972, Pennsylvanian and Permian stratigraphy and tectonism in central Colorado: Quarterly of the Colorado School of Mines, v. 67, no. 4, p. 139-185.

De Voto, R.H., Bartleson, B.L., Schenk, C.J., and Waechter, N.C., 1986, Late Paleozoic stratigraphy and syndepositional tectonism, northwestern Colorado, in Stone, D.S., ed., New interpretations of northwest Colorado geology: Rocky Mountain Association of Geologists, p. 37-50.

Dott, R.H., Jr., and Bourgeois, J., 1982, Hummocky stratification-Significance of its variable bedding sequences: Geological Society of America Bulletin, v. 93, p. $663-680$.

Driese, S.G., and Dott, R.H., Jr., 1984, Model for sandstonecarbonate "cyclothems" based on Upper Member of Morgan Formation (Middle Pennsylvanian) of northern Utah and Colorado: American Association of Petroleum Geologists Bulletin, v. 68, p. 574-597. 
Elliot, T., 1986, Siliciclastic shorelines, in Reading, H.G., ed., Sedimentary environments and facies (2nd ed.): Oxford, Blackwell Scientific Publications, p. 155-188.

Evans, G., 1979, Quaternary transgressions and regressions: Journal of the Geological Society of London, v. 136, p. 125-132.

Friend, P.F., Slater, M.J., and Williams, R.C., 1979, Vertical and lateral building of river sandstone bodies, Ebro basin, Spain: Journal of the Geological Society of London, v. 136 , p. $39-46$.

Galloway, W.E., 1989, Genetic stratigraphic sequences in basin analysis, I, Architecture and genesis of flooding-surface bounded depositional units: American Association of Petroleum Geologists Bulletin, v. 73, p. 125-142.

Goodwin, P.W., and Anderson, E.J., 1985, Punctuated aggradational cycles-A general hypothesis of episodic stratigraphic accumulation: Journal of Geology, v. 93, p. 515-533.

Harms, J.C., 1979, Primary sedimentary structures: Annual Reviews of Earth and Planetary Science, v. 7, p. 227-248.

Harms, J.C., Southard, J.B., and Walker, R.G., 1982, Structures and sequences in clastic rocks: Society of Economic Paleontologists and Mineralogists, Lecture Notes for Short Course 9, p. 1-1-8-51.

Hartman, W.D., Wendt, J.W., and Wiedemayer, F., 1980, Living and fossil sponges: Sedimenta, v. 8, 274 p.

Hayward, A.B., 1985, Coastal alluvial fans (fan deltas) of the Gulf of Aqaba (Gulf of Eilat), Red Sea: Sedimentary Geology, v. 43 , p. $241-260$.

Heckel, P.H., 1986, Sea-level curve for Pennsylvanian eustatic marine transgressive-regressive cycles along midcontinent outcrop belt, North America: Geology, v. 14, p. 330-334.

Heward, A.P., 1978, Alluvial fan sequence and megasequence models with examples from Westphalian D-Stephanian B coalfields, Northern Spain, in Miall, A.D., ed., Fluvial sedimentology: Canadian Society of Petroleum Geologists Memoir 5, p. 669-702.

Hite, R.J., Anders, D.E., and Ging, T.G., 1984, Organic-rich source rocks of Pennsylvanian age in the Paradox basin of Utah and Colorado, in Woodward, J., Meissner, F.F., and Clayton, J.L., eds., Source rocks of the Rocky Mountains: Rocky Mountain Association of Geologists, p. 147-159.

Houck, K., and Lockley, M., 1986, A field guide to the Pennsylvanian biofacies of the Minturn Formation, BondMcCoy area, central Colorado trough: University of Colorado at Denver, Geology Department Magazine, Special Issue 2, $64 \mathrm{p}$.

Imbrie, J., and Imbrie, J.W., 1980, Modelling the climatic response to orbital variations: Science, v. 207, p. 943-953.

Johnson, S.Y., 1986, Water-escape structures in coarse-grained, volcaniclastic, fluvial deposits of the Ellensburg Formation, south-central Washington: Journal of Sedimentary Petrology, v. 56, p. 905-910.

1987, Sedimentology and paleogeographic significance of six fluvial sandstone bodies in the Maroon Formation, Eagle basin, northwest Colorado: U.S. Geological Survey Bulletin 1787-A, 18 p.
1989, The Fryingpan Member of the Maroon Formation-A Lower Permian (?) basin-margin dune field in northwestern Colorado: U.S. Geological Survey Bulletin 1787-I, $11 \mathrm{p}$.

Johnson, S.Y., Schenk, C.J., and Karachewski, J.A., 1988, Pennsylvanian and Permian depositional systems and cycles in the Eagle basin, Northwest Colorado, in Holden, G.S., ed., Geological Society of America Centennial Meeting, field trip guidebook: Professional Contributions of Colorado School of Mines, Number 12, p. 156-174.

Karachewski, J.A., 1990, Facies analysis, genetic sequences, and paleogeography of the lower Minturn Formation (Middle Pennsylvanian), southeastern Eagle basin, Colorado: Golden, Colorado School of Mines, Ph.D. dissertation, $153 \mathrm{p}$.

Kluth, C.F., 1986, Plate tectonics of the Ancestral Rocky Mountains, in Peterson, J.A., ed., Paleotectonics and sedimentation in the Rocky Mountain region, United States: American Association of Petroleum Geologists Memoir 41, p. 353-370.

Leeder, M.R., Ord, D.M., and Collier, R., 1988, Development of alluvial fans and fan deltas in neotectonic extensional settings-Implications for the interpretation of basin fills, in Nemec, W., and Steel, R.J., eds., Fan deltas-Sedimentology and tectonic setting: Glasgow and London, Blackie and Son, p. 173-185.

Lowe, D.R., 1975, Water escape structures in coarse-grained sediments: Sedimentology, v. 22, p. 157-204.

Mack, G.H., and Rasmussen, K.A., 1984, Alluvial fan sedimentation of the Cutler Formation (PermoPennsylvanian) near Gateway, Colorado: Geological Society of America Bulletin, v. 95, p. 109-116.

Mallory, W.W., 1971, The Eagle Valley Evaporite, northwest Colorado-A regional synthesis: U.S. Geological Survey Bulletin 1311-E, p. E1-E37.

1972, Regional synthesis of the Pennsylvanian system, in Mallory, W.W., ed., Geologic atlas of the Rocky Mountain region: Rocky Mountain Association of Geologists, p. 111-127.

Massari, F., and Colella, A., 1988, Evolution and types of fan-delta systems in some major tectonic setting, in Nemec, W., and Steel, R.J., eds., Fan deltas-Sedimentology and tectonic setting: Glasgow and London, Blackie and Son, p. 103-124.

Middleton, G.V., and Hampton, M.A., 1973, Sediment gravity flows: mechanics of flow and deposition, in Middleton, G.V., and Bouma, A.H., cochairmen, Turbidites and deepwater sedimentation: Society of Economic Paleontologists and Mineralogists, Pacific Section, Short Course Notes, p. 1-38.

Mitchum, R.M., Jr., 1977, Seismic stratigraphy and global changes of sea level, Part 1, Glossary of terms used in seismic stratigraphy, in Payton, C.E., ed., Seismic stratigraphyApplications to hydrocarbon exploration: American Association of Petroleum Geologists Memoir 26, p. 205-212.

Mitchum, R.M., Jr., Vail, P.R., and Sangree, J.B., 1977, Seismic stratigraphy and global changes of sea level, Part 6, Stratigraphic interpretation of seismic reflection patterns in 
depositional sequences, in Payton, C.E., ed., Seismic stratigraphy-Applications to hydrocarbon exploration: American Association of Petroleum Geologists Memoir 26, p. 117-133.

Mitchum, R.M., Jr., Vail, P.R., and Thompson, III, S., Seismic stratigraphy and global changes of sea level, Part 2, The depositional sequence as a basic unit for stratigraphic analysis, in Payton, C.E., ed., Seismic stratigraphy-Applications to hydrocarbon exploration: American Association of Petroleum Geologists Memoir 26, p. 53-62.

Nemec, W., and Steel, R.J., 1984, Alluvial and coastal conglomerates: their significant features and some comments on gravelly mass-flow deposits, in Koster, E.H., and Steel, R.J., eds., Sedimentology of gravels and conglomerates: Canadian Society of Petroleum Geologists Memoir 10, p. 1-31.

Nummedal D., and Swift, D.J.P., 1987, Transgressive stratigraphy at sequence-bounding unconformities-Some principles derived from Holocene and Cretaceous examples, in Nummedal, D., and others, eds., Sea-level fluctuation and coastal evolution: Society of Economic Paleontologists and Mineralogists Special Publication 41, p. 241-259.

Postma, G., 1983, Water escape structures in the context of a depositional model of a mass flow dominated conglomeratic fan-delta (Abrioja Formation, Pliocene, Almeria basin, SE Spain): Sedimentology, v. 30, p. 91-103.

Postma, G., and Roep, T.B., 1985, Resedimented conglomerates in the bottomsets of Gilbert-type gravel deltas: Journal of Sedimentary Petrology, v. 55, p. 874-885.

Read, C.B., and Mamay, S.H., 1964, Upper Paleozoic floral zones and floral provinces of the United States: U.S. Geological Survey Professional Paper 454 K, 34 p.

Reineck, H.E., and Singh, I.B., 1980, Depositional sedimentary environments (2nd ed.): New York, Springer-Verlag, 549 p.

Rust, B.R., and Koster, E.H., 1984, Coarse alluvial deposits, in Walker, R.G., ed., Facies models (2nd ed.): Geoscience Canada Reprint Series 1, p. 53-69.

Schenk, C.J., 1987, Sedimentology of an eolian sandstone from the Middle Pennsylvanian Eagle Valley Evaporite, Eagle basin, northwest Colorado: U.S. Geological Survey Bulletin 1787B, p. 20-28.

1989 , Sedimentology and stratigraphy of the Eagle Valley Evaporite (Middle Pennsylvanian), Eagle basin, northwest Colorado: Boulder, University of Colorado, Ph.D. thesis, $172 \mathrm{p}$.

Schumm, S.A., 1977, The fluvial system: New York, John Wiley and Sons, $338 \mathrm{p}$.

Schwartz, R.K., 1982, Bedform and stratification characteristics of some modern small-scale washover sand bodies: Sedimentology, v. 29, p. 835-849.

Shultz, A.W., 1984, Subaerial debris-flow deposition in the Upper Paleozoic Cutler Formation, western Colorado: Journal of Sedimentary Petrology, v. 54, p. 759-772.
Stevens, C.H., 1965, Faunal trends in near-shore Pennsylvanian deposits near McCoy, Colorado: The Mountain Geologist, v. 2 , no. 2 , p. $71-77$.

1971, Distribution and diversity of Pennsylvanian marine faunas relative to water depth and distance from shore: Lethia, v. 4, p. 403-412.

Swift, D.J.P., 1968, Coastal erosion and transgressive stratigraphy: Journal of Geology, v. 76, p. $444-456$.

Thompson, R.W., 1968, Tidal flat sedimentation on the Colorado River delta, northwestern Gulf of California, Geological Society of America Memoir 107, 133 p.

Tillman, R.W., 1971, Petrology and paleoenvironments, Robinson Member, Minturn Formation (Desmoinesian), Eagle basin, northwest Colorado: American Association of Petroleum Geologists Bulletin, v. 55, p. 593-620.

Tucker, M.E., 1982, The field description of sedimentary rocks: Milton Keynes, Open University Press and The Geological Society of London Handbook Series, 112 p.

Tweto, O., 1949, Stratigraphy of the Pando area, Eagle County, Colorado: Colorado Scientific Society Proceedings, v. 15, p. 149-235.

1977, Tectonic history of west-central Colorado, in Veal, H.K., ed., Exploration frontiers of the central and southern Rockies: Rocky Mountain Association of Geologists, p. 11-22.

1980, Tectonic history of Colorado, in Kent, H.C., and Porter, K.W., eds., Colorado geology: Rocky Mountain Association of Geologists, p. 5-9.

Tweto, O., and Lovering, T.S., 1977, Geology of the Minturn 15' Quadrangle, Eagle and Summit Counties, Colorado: U.S. Geological Survey Professional Paper 956, 96 p.

Tweto, O., Moench, R.H., and Reed, J.C., Jr., 1978, Geologic map of the Leadville $1^{\circ} \times 2^{\circ}$ quadrangle, northwestern Colorado: U.S. Geological Survey Miscellaneous Investigations Series I-999, scale 1:250:000.

Van Wagoner, J.C., Posamentier, H.W., Mitchum, R.M., Vail, P.R., Sarg, J.F., Loutit, T.S., and Hardenbol, J., 1988, An overview of the fundamentals of sequence stratigraphy and key definitions, in Wilgus, C.K. and others, eds., Sea-level changes-An integrated approach: Society of Economic Paleontologists and Mineralogists Special Publication 42, p. $39-45$.

Waechter, N.B., and Johnson, W.E., 1985, Seismic interpretation in the Piceance basin, northwest Colorado, in Gries, R.R., and Dyer, R.C., eds., Seismic exploration of the Rocky Mountain region: Rocky Mountain Association of Geologists and Denver Geophysical Society, p. 247-258.

Walker, R.G., 1979, Shallow marine sands, in Walker, R.G., ed., Facies models: Geoscience Canada Reprint Series 1, p. 75-89.

Walker, T.R., 1972, Bioherms in the Minturn Formation (Desmoinesian age), Vail-Minturn area, Eagle County, Colorado: Quarterly of the Colorado School of Mines, v. 67, no. 4 , p. 249-278. 